Geosci. Model Dev., 10, 3745-3770, 2017

https://doi.org/10.5194/gmd-10-3745-2017

(C) Author(s) 2017. This work is distributed under

the Creative Commons Attribution 3.0 License.

\title{
A representation of the phosphorus cycle for ORCHIDEE (revision 4520)
}

\author{
Daniel S. Goll $^{1}$, Nicolas Vuichard ${ }^{1}$, Fabienne Maignan ${ }^{1}$, Albert Jornet-Puig ${ }^{1}$, Jordi Sardans ${ }^{2,3}$, Aurelie Violette ${ }^{4}$, \\ Shushi Peng ${ }^{6}$, Yan Sun ${ }^{6}$, Marko Kvakic $^{7}$, Matthieu Guimberteau ${ }^{1,8}$, Bertrand Guenet ${ }^{1}$, Soenke Zaehle ${ }^{5}$, \\ Josep Penuelas $^{2,3}$, Ivan Janssens ${ }^{9}$, and Philippe Ciais ${ }^{1}$ \\ ${ }^{1}$ Le Laboratoire des Sciences du Climat et de l'Environnement, IPSL-LSCE CEA/CNRS/UVSQ Saclay, \\ Gif-sur-Yvette, France \\ ${ }^{2}$ CSIC, Global Ecology Unit CREAF-CSIC-UAB, 08193 Bellaterra, Catalonia, Spain \\ ${ }^{3}$ CREAF, 08193 Cerdanyola del Vallés, Catalonia, Spain \\ ${ }^{4}$ LMTG - Laboratoire des Mécanismes et Transfert en Géologie, Toulouse, France \\ ${ }^{5}$ Biogeochemical Integration Department, Max Planck Institute for Biogeochemistry, 07701 Jena, Germany \\ ${ }^{6}$ Sino-French Institute for Earth System Science, College of Urban and Environmental Sciences, Peking University, \\ Beijing, 100871, China \\ ${ }^{7}$ ISPA, Bordeaux Sciences Agro, INRA, 33140 Villenave-d'Ornon, France \\ ${ }^{8}$ Sorbonne Universités, UPMC, CNRS, EPHE - UMR7619 METIS, 75252 Paris, France \\ ${ }^{9}$ Department of Biology, University of Antwerp, Universiteitsplein 1, 2610 Wilrijk, Belgium
}

Correspondence to: Daniel S. Goll (daniel.goll@1sce.ipsl.fr)

Received: 9 March 2017 - Discussion started: 12 April 2017

Revised: 25 July 2017 - Accepted: 28 August 2017 - Published: 12 October 2017

\begin{abstract}
Land surface models rarely incorporate the terrestrial phosphorus cycle and its interactions with the carbon cycle, despite the extensive scientific debate about the importance of nitrogen and phosphorus supply for future land carbon uptake. We describe a representation of the terrestrial phosphorus cycle for the ORCHIDEE land surface model, and evaluate it with data from nutrient manipulation experiments along a soil formation chronosequence in Hawaii.

ORCHIDEE accounts for the influence of the nutritional state of vegetation on tissue nutrient concentrations, photosynthesis, plant growth, biomass allocation, biochemical (phosphatase-mediated) mineralization, and biological nitrogen fixation. Changes in the nutrient content (quality) of litter affect the carbon use efficiency of decomposition and in return the nutrient availability to vegetation. The model explicitly accounts for root zone depletion of phosphorus as a function of root phosphorus uptake and phosphorus transport from the soil to the root surface.
\end{abstract}

The model captures the observed differences in the foliage stoichiometry of vegetation between an early (300-year) and a late (4.1 Myr) stage of soil development. The contrasting sensitivities of net primary productivity to the addition of either nitrogen, phosphorus, or both among sites are in general reproduced by the model. As observed, the model simulates a preferential stimulation of leaf level productivity when nitrogen stress is alleviated, while leaf level productivity and leaf area index are stimulated equally when phosphorus stress is alleviated. The nutrient use efficiencies in the model are lower than observed primarily due to biases in the nutrient content and turnover of woody biomass.

We conclude that ORCHIDEE is able to reproduce the shift from nitrogen to phosphorus limited net primary productivity along the soil development chronosequence, as well as the contrasting responses of net primary productivity to nutrient addition. 


\section{Introduction}

As it has been acknowledged that human activity is changing Earth's climate, it is argued that climate research needs to sharpen its view (Marotzke et al., 2017). As its new suggested focus is the fate of the emitted carbon, which is closely linked to the extensive scientific debate about the importance of nutrient limitation (nitrogen and phosphorus supply) for future land carbon uptake (for example, Peñuelas et al., 2013; Wieder et al., 2015; Brovkin and Goll, 2015). Yet none of the Earth system models (ESMs), which are major tools in advancing the understanding of the role of human activities in the climate system, incorporate a terrestrial phosphorus cycle.

The few existing land surface models (LSMs) which account for interactions between phosphorus availability and the land carbon cycle suggest a significant role of phosphorus availability for ecosystems on highly weathered soils (Wang et al., 2010; Goll et al., 2012; Yang et al., 2014) with increasing significance as carbon dioxide concentration rises (Goll et al., 2012). However, these findings are highly uncertain due to processes which are poorly constrained by current observational data: soil phosphorus sorption dynamics, phosphatase-mediated mineralization, stoichiometric plasticity, leaf nutrient recycling, and the effects of phosphorus limitation on vegetation (photosynthesis, growth, allocation, mortality) (Wang et al., 2010; Goll et al., 2012; Yang et al., 2014; Reed et al., 2015).

Ecosystem manipulation experiments are shown to provide useful information to assess and evaluate LSMs (Medlyn et al., 2015; Meyerholt and Zaehle, 2015), which, in return, facilitate the interpretation of observation data and can guide the design of experiments (Medlyn et al., 2015). The long-term (6-10-year) fertilization experiment in a soil formation chronosequence in Hawaii (Harrington et al., 2001; Ostertag, 2001), with its contrasting availabilities of nitrogen and phosphorus along a soil age gradient going from young phosphorus-rich and nitrogen-poor soils to old highly weathered soils low in phosphorus but rich in nitrogen, provides an ideal test case for the evaluation of nutrient components in LSMs (Wang et al., 2007; Yang et al., 2014).

The potentially important influence of phosphorus availability on the land carbon balance and the recently initiated ecosystem-scale manipulation experiments in phosphoruspoor environments (for example, Ama, 2017; Euc, 2017; IMB, 2017; AFE, 2017) as well as other projects related to the role of phosphorus in ecosystem functioning (for example, SPP, 2017; QUI, 2017), call for the need for new phosphorus enabled LSMs to keep track of these actions (Reed et al., 2015).

Here, we describe the implementation of the terrestrial phosphorus cycle in the ORCHIDEE LSM (Krinner et al., 2005) following the principles developed earlier for the introduction of the nitrogen cycle into ORCHIDEE (Zaehle and Friend, 2010). It is the first global phosphorus model which explicitly simulates root uptake of dissolved phosphorus accounting for soil moisture effects on soil phosphorus mobility. The model is then evaluated with data from a long-term fertilization experiment in a soil formation chronosequence in Hawaii (Harrington et al., 2001; Ostertag, 2001).

\section{Methods}

\subsection{Model description}

The land surface model used for this study, ORCHIDEE, is based on two different modules (Krinner et al., 2005, their Fig. 2). The first module describes the fast processes such as the soil water budget and the exchanges of energy, water, and $\mathrm{CO}_{2}$ through photosynthesis between the atmosphere and the biosphere. The second module simulates the carbon dynamics of the terrestrial biosphere and essentially represents processes such as maintenance and growth respiration, carbon allocation, litter decomposition, soil carbon dynamics, and phenology. Global vegetation is described by 13 metaclasses which correspond to plant functional types (PFTs) with a specific parameter set (one for bare soil, eight for forests, two for grasslands, and two for croplands).

The major modifications since Krinner et al. (2005) are listed in the following: a slightly revised carbon allocation scheme from a recent side branch of ORCHIDEE (Naudts et al., 2015), which avoids the capping of the leaf area index at a predefined value; an explicit representation of mesophylic conductance to $\mathrm{CO}_{2}$ and omission of direct effects of soil moisture stress on the maximum rate of carboxylation $\left(V_{\mathrm{cmax}}\right)$ (Vuichard, unpublished data); and a revised thermodynamic scheme which accounts for the heat transported by liquid water into the soil, in addition to the heat conduction process (Wang et al., 2016).

\subsubsection{Starting version}

The implementation of the phosphorus $(\mathrm{P})$ cycle in ORCHIDEE was done in the nitrogen enabled version of ORCHIDEE (ORCHIDEE-CN) (Vuichard, 2017 unpublished data). ORCHIDEE-CN is a re-implementation of the nitrogen cycle from a discontinued version of ORCHIDEE (which became OCN, Zaehle and Friend, 2010; Zaehle et al., 2011) in a recent version of ORCHIDEE (r3623). The nitrogen cycle in OCN is well evaluated (De Kauwe et al., 2014; Zaehle et al., 2014; Walker et al., 2015; Meyerholt and Zaehle, 2015) and identical to the one in ORCHIDEE-CN except for the parametrization of the relationship between leaf nitrogen concentration and maximum carboxylation capacity of photosynthesis $\left(V_{\text {cmax }}\right)$ as ORCHIDEE (r3623) uses a different carbon assimilation scheme than originally used in Zaehle and Friend (2010). $V_{\mathrm{cmax}}$ is directly derived from the leaf nitrogen concentration at the respective canopy level following Kattge et al. (2009): 


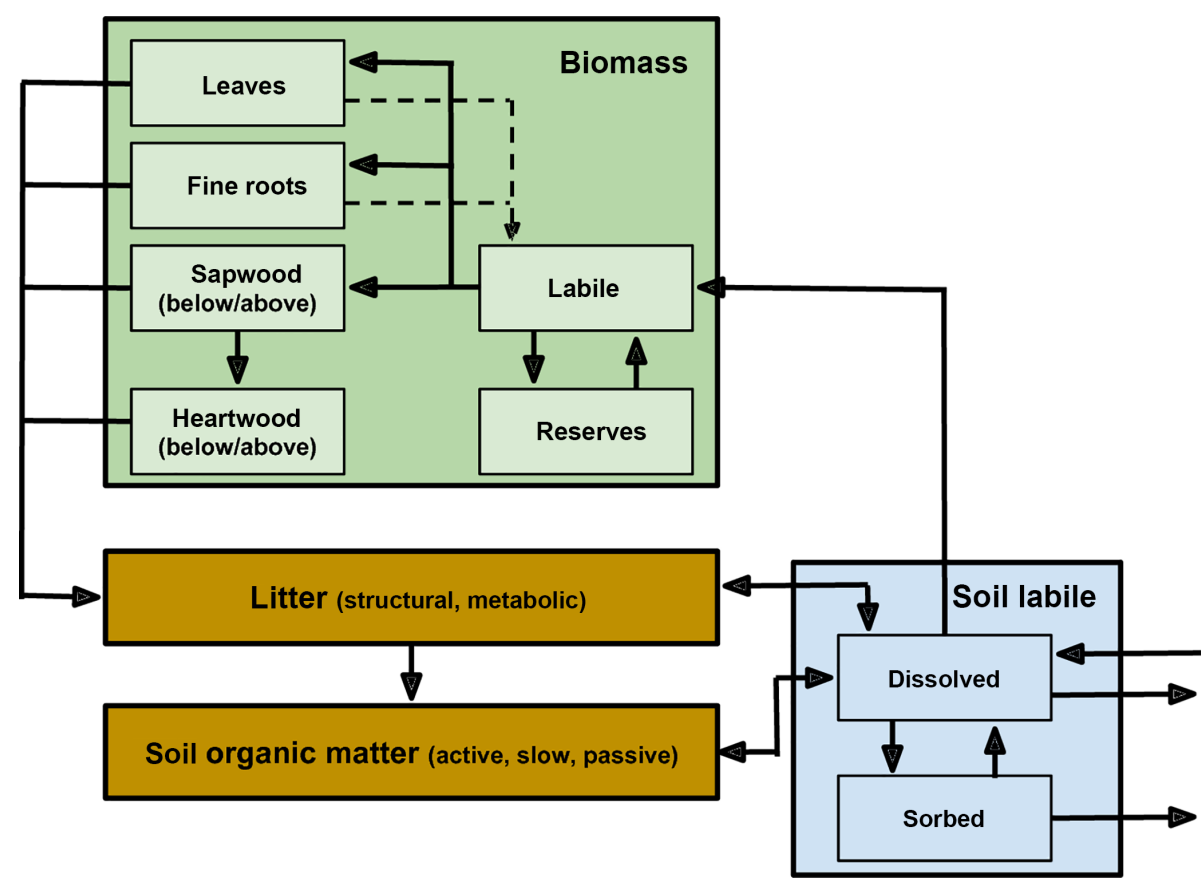

Figure 1. Pools and fluxes of the phosphorus component of ORCHIDEE: phosphorus enters ecosystems in the form of dissolved labile phosphorus from chemical weathering of minerals and atmospheric deposition. Dissolved labile phosphorus is the sole source for plants and microbes and can be reversibly adsorbed onto soil particles or lost by leaching. Adsorbed labile phosphorus can be transformed into more recalcitrant forms which are irreversibly lost to biota. When plants take up phosphorus from soils it enters the plant labile phosphorus pool, from which it is allocated to growing plant tissues. The plant labile phosphorus concentration is buffered by a reserve pool which serves as a long-term storage to buffer seasonal variations in phosphorus demand and supply. When plant tissue is shed, part of the phosphorus is recycled (broken lines), while the rest enters the litter pools, from where it is either transformed into soil organic matter or mineralized.

$V_{\mathrm{cmax}, h}=$ nueN $_{\text {leaf }, h}^{*}$

where $\mathrm{N}_{\text {leaf }, h}^{*}$ is nitrogen concentration in leaves at canopy level $(h) . \mathrm{N}_{\text {leaf }, h}^{*}$ is derived from nitrogen in leaf biomass per ground area $\left(\mathrm{N}_{\text {leaf }}\right)$ using an exponential canopy nitrogen profile (Johnson and Thornley, 1984). $\mathrm{N}_{\text {leaf, } h}^{*}$ is corrected for a certain fraction of structural nitrogen per leaf carbon $\left(\mathrm{N}_{\mathrm{str}}\right)$ which does not contribute directly to the carboxylation capacity of photosynthesis (Table 2):

$\mathrm{N}_{\text {leaf }, h}^{*}=\left(\mathrm{N}_{\text {leaf }}-\mathrm{N}_{\text {str }}\right) \exp \left(-\kappa_{N} h\right)$,

where $\kappa_{N}$ is the extinction coefficient. The electron transport capacity $\left(J_{\max , \mathrm{h}}\right)$ is derived from $V_{\mathrm{cmax}, h}$ using the relationship from Kattge and Knorr (2007) which accounts for acclimation of photosynthesis to monthly temperatures.

In the following the representation of the terrestrial phosphorus cycle and its interaction with the cycles of carbon and nitrogen are described. All variables and parameters can be found in Tables 1 and 2, respectively.

\subsubsection{Vegetation: phosphorus uptake, allocation, and turnover}

Vegetation biomass (carbon, nitrogen, and phosphorus) is separated into leaves, roots, sapwood, heartwood, and short- term (labile) and long-term storage (reserves) (Zaehle and Friend, 2010; Naudts et al., 2015) (Fig. 1). We prescribed boundaries for the stoichiometry of leaves, roots, sapwood, and heartwood, but not for labile and reserves (Table A1) (Zaehle and Friend, 2010).

Plants take up labile phosphorus dissolved in soil solution (solution phosphorus) following the representation of root nitrogen uptake (Zaehle and Friend, 2010). Plant nutrient uptake is simulated as a function of mineral nutrient availability with the aim to account for the increase in uptake in nutrient starved plants by increasing the uptake capacity per root surface (Schachtman et al., 1998), as well as indirectly through increased root growth and exploration of the soil by roots to increase their resource acquisition (Schachtman et al., 1998). Mycorrhizae are implicitly included in root biomass as mycorrhizal hyphae show comparable uptake characteristics as roots (Schachtman et al., 1998). As the concentration of phosphorus in roots is orders of magnitudes larger than the concentration in the soil solution, passive uptake of phosphorus via diffusion is negligible (Schachtman et al., 1998). Thus, only active uptake via specialized transporters on the root surface is accounted for in the model. Hereby, the model does not distinguish between organic and inorganic forms of dissolved labile phosphorus. 
Table 1. Variables of the model.

\begin{tabular}{|c|c|c|}
\hline Variable & Units & Description \\
\hline$V_{\text {cmax }, h}$ & $\mu \mathrm{mol}\left(\mathrm{CO}_{2}\right) \mathrm{m}^{-2} \mathrm{~s}^{-1}$ & maximum carboxylation rate of photosynthesis at canopy level $h ; h \in\{1,2, \ldots, 20\}$ per leaf area \\
\hline$J_{\max , \mathrm{h}}$ & $\mu \mathrm{mol}\left(\mathrm{CO}_{2}\right) \mathrm{m}^{-2} \mathrm{~s}^{-1}$ & maximum electron transport capacity of photosynthesis at canopy level $h ; h \in\{1,2, \ldots, 20\}$ per leaf area \\
\hline $\mathrm{N}_{\text {leaf }, h}^{*}$ & $\mathrm{~g}(\mathrm{~N}) \mathrm{m}^{-2}$ & leaf nitrogen concentration at canopy level $h ; h \in\{1,2, \ldots, 20\}$ per leaf area \\
\hline$u_{\max }$ & $g(P) g^{-1}(C) t^{-1}$ & root uptake capacity \\
\hline $\mathrm{C}_{i}$ & $\mathrm{~g}(\mathrm{C}) \mathrm{m}^{-2}$ & carbon in plant tissue $i ; i \in\{$ leaf, root, sapwood, heartwood, coarse root, fruit $\}$ \\
\hline$a_{\text {root }}$ & - & relative reduction in dissolved phosphorus concentration at root surface \\
\hline$\Theta$ & $\mathrm{mm}$ & soil water content \\
\hline $\mathrm{P}_{\text {sol }}$ & $\mathrm{g}(\mathrm{P}) \mathrm{m}^{-2}$ & dissolved labile phosphorus in soil \\
\hline $\mathrm{P}_{\text {sorb }}$ & $\mathrm{g}(\mathrm{P}) \mathrm{m}^{-2}$ & adsorbed labile phosphorus in soil \\
\hline$F_{\text {up }}$ & $\mathrm{g}(\mathrm{P}) \mathrm{m}^{-2} \mathrm{t}^{-1}$ & phosphorus uptake of vegetation \\
\hline$T_{\text {soil }}$ & $\mathrm{K}$ & soil temperature \\
\hline$f \mathrm{PN}_{\text {plant }}$ & - & scaling function \\
\hline$f_{\text {temp }}$ & - & temperature scaling function of biological activity \\
\hline $\mathrm{pn}_{\text {plant }}$ & $g(P) g^{-1}(N)$ & phosphorus to nitrogen ratio of active and easily translocatable portion of plant nutrients \\
\hline $\mathrm{P}_{i}$ & $\mathrm{~g}(\mathrm{P}) \mathrm{m}^{-2}$ & phosphorus in plant tissue $i ; i \in\{$ leaf, root, sapwood, heartwood, coarse root, fruit $\}$ \\
\hline $\mathrm{N}_{i}$ & $\mathrm{~g}(\mathrm{~N}) \mathrm{m}^{-2}$ & nitrogen in plant tissue $i ; i \in\{$ leaf, root, sapwood, heartwood, coarse root, fruit $\}$ \\
\hline$G_{\mathrm{P}}$ & $\mathrm{g}(\mathrm{P}) \mathrm{m}^{-2} \mathrm{t}^{-1}$ & phosphorus allocated to growth \\
\hline$F_{\text {reserve }}$ & $\mathrm{g}(\mathrm{P}) \mathrm{m}^{-2} \mathrm{t}^{-1}$ & flux between plant labile and reserve phosphorus pools \\
\hline$P_{\text {labile, } \max }$ & $\mathrm{g}(\mathrm{P}) \mathrm{m}^{-2}$ & maximum size of plant labile phosphorus pool \\
\hline$D_{\text {leaf }}$ & - & empirical elasticity parameter for stoichiometry \\
\hline $\mathrm{pn}_{\text {leaf }}$ & $\mathrm{g}(\mathrm{P}) \mathrm{g}^{-1}(\mathrm{~N})$ & foliage phosphorus to nitrogen ratio \\
\hline $\mathrm{nc}_{\text {leaf }}$ & $\mathrm{Pg}(\mathrm{N}) \mathrm{g}^{-1}(\mathrm{C})$ & foliage nitrogen to carbon ratio \\
\hline$G_{\mathrm{C}}$ & $\mathrm{g}(\mathrm{C}) \mathrm{m}^{-2} \mathrm{t}^{-1}$ & carbon allocated to growth \\
\hline$g_{\max }$ & 0.95 & daily fraction of $\mathrm{P}_{\text {labile }}$ available for growth \\
\hline$p_{\lim }$ & - & growth limitation factor derived from phosphorus availability \\
\hline$n_{\lim }$ & - & growth limitation factor derived from nitrogen availability \\
\hline$n p_{\lim }$ & - & actual growth limitation factor \\
\hline$n_{\mathrm{scal}, \mathrm{P}}$ & - & scaling factor for allocation derived from phosphorus availability \\
\hline$n_{\text {scal,N }}$ & - & scaling factor for allocation derived from nitrogen availability \\
\hline$n_{\text {scal }}$ & - & actual scaling factor for allocation \\
\hline $\mathrm{pc}_{\text {plant }}$ & $\mathrm{g}(\mathrm{P}) \mathrm{g}^{-1}(\mathrm{C})$ & growing season average of the plant labile phosphorus to labile carbon concentrations \\
\hline$F_{\text {bcm }}$ & $\mathrm{g}(\mathrm{P}) \mathrm{m}^{-2} \mathrm{t}^{-1}$ & biochemical mineralization rate of phosphorus \\
\hline $\mathrm{P}_{x}$ & $\mathrm{~g}(\mathrm{P}) \mathrm{m}^{-2}$ & phosphorus in soil organic matter $x ; x \in\{$ active, slow, stable $\}$ \\
\hline$F_{\text {leach }}$ & $\mathrm{g}(\mathrm{P}) \mathrm{m}^{-2} \mathrm{t}^{-1}$ & dissolved labile phosphorus losses by leaching \\
\hline$F_{\text {weath }}$ & $\mathrm{g}(\mathrm{P}) \mathrm{m}^{-2} \mathrm{t}^{-1}$ & phosphorus release from primary minerals \\
\hline$F_{\min }$ & $\mathrm{g}(\mathrm{P}) \mathrm{m}^{-2} \mathrm{t}^{-1}$ & phosphorus release from primary minerals \\
\hline$F_{\text {diff }}$ & $\mathrm{g} \mathrm{m}^{-2} \mathrm{t}^{-1}$ & diffusion of phosphorus to the root zone \\
\hline$\Delta \mathrm{P}_{\mathrm{sol}}$ & $\mathrm{g}(\mathrm{P}) \mathrm{m}^{-3}$ & root zone concentration gradient \\
\hline$\alpha_{\text {root }}$ & - & relative reduction of dissolved labile phosphorus in soil solution at the root \\
\hline$D$ & $\mathrm{mt}^{-1}$ & soil permeability to phosphorus \\
\hline$r_{\text {diff }}$ & $\mathrm{m}$ & half distance between root cylinders \\
\hline & - & tortuosity factor of diffusion \\
\hline RLD & $\mathrm{mm}^{-3}$ & root length per volume of soil \\
\hline$M_{\text {root }}^{*}$ & $\mathrm{~g}(\mathrm{C}) \mathrm{m}^{-3}$ & root biomass density in soil volume \\
\hline
\end{tabular}

The $x$ root uptake capacity $\left(u_{\max }\right)$ per root mass $\left(\mathrm{C}_{\text {root }}\right)$ for a given solute concentration follows the combined behavior of low-affinity and high-affinity transporter systems working in parallel, which typically shows no saturation at high soil solute concentrations (Kronzucker et al., 1995; Zhang et al., 2009) and is given by

$u_{\max }=v_{\max } a_{\text {root }} \mathrm{P}_{\text {sol }}\left(\frac{k_{\mathrm{P}_{\text {min }}}}{c_{k}}+\frac{1}{\mathrm{P}_{\mathrm{sol}}+c_{k} k_{\mathrm{P}_{\min }}}\right)$ where $v_{\max }$ is the maximum uptake capacity, $a_{\text {root }} \frac{\mathrm{P}_{\mathrm{sol}}}{\Theta}$ is the dissolved labile phosphorus concentration at the root surface (Eq. 23), and $c_{k}$ a unit conversion factor using the soil-typespecific parameter for soil moisture content at saturation in ORCHIDEE ( $m c s$ ) as an approximation of pore space following Smith et al. (2014).

The combined behavior of the two uptake systems is approximated by the term in brackets, where the linear factor $\left(k_{\mathrm{P}_{\min }}\right)$ was chosen to match the observed rate of increase 
Table 2. Parameters of the model.

\begin{tabular}{|c|c|c|c|c|}
\hline Parameter & Value & Units & Description & Source \\
\hline$t$ & 0.0208333 & day & time step of $30 \mathrm{~min}$ & - \\
\hline nue & PFT specific & $\mu \mathrm{mol}\left(\mathrm{CO}_{2}\right) \mathrm{g}^{-1}(\mathrm{~N}) \mathrm{s}^{-1}$ & nitrogen use efficiency of photosynthesis & Kattge et al. (2009) \\
\hline $\mathrm{N}_{\text {str }}$ & 4. $\times 10^{-3}$ & $\mathrm{~g}(\mathrm{~N}) \mathrm{g}^{-1}(\mathrm{C})$ & structural leaf nitrogen & Ali et al. (2016) \\
\hline$\kappa_{N}$ & 0.11 & $\mathrm{~m}^{2} \mathrm{~m}^{-2}$ & canopy nitrogen extinction coefficient & Zaehle and Friend (2010) \\
\hline$v_{\max }$ & $4.31 \times 10^{-6}$ & $g(P) g(C) t^{-1}$ & maximal uptake capacity of roots & calibrated \\
\hline$k_{\mathrm{P}_{\min }}$ & 3.0 & $\mu \mathrm{mol}(\mathrm{P}) 1^{-1}$ & dissolved phosphorus concentration at which uptake equals $\frac{v_{\max }}{2}$ & Schachtman et al. (1998) \\
\hline$k_{\mathrm{P}_{\min }}$ & 0.01 & $\mu \mathrm{mol}(\mathrm{P}) 1^{-1}$ & linear increase in $\mathrm{p}$ uptake for high phosphorus concentrations & calibrated Zhang et al. (2009) \\
\hline$c_{k}$ & depends on soil order & $\lg (\mathrm{P})^{-1}$ & unit conversion factor & this study \\
\hline$T_{\text {soil, ref }}$ & 303.15 & $\mathrm{~K}$ & reference soil temperature & (Zaehle and Friend, 2010) \\
\hline $\mathrm{pn}_{\text {leaf, } \min }$ & PFT specific & $\mathrm{g}(\mathrm{P}) \mathrm{g}^{-1}(\mathrm{~N})$ & minimum foliage phosphorus to nitrogen ratio & McGroddy et al. (2004) \\
\hline $\mathrm{pn}_{\text {leaf, } \max }$ & PFT specific & $\mathrm{g}(\mathrm{P}) \mathrm{g}^{-1}(\mathrm{~N})$ & maximum foliage phosphorus to nitrogen ratio & McGroddy et al. (2004) \\
\hline $\mathrm{nc}_{\text {leaf, } \min }$ & PFT specific & $\operatorname{Pg}(\mathrm{N}) \mathrm{g}^{-1}(\mathrm{C})$ & minimum foliage nitrogen to carbon ratio & Zaehle and Friend (2010) \\
\hline $\mathrm{nc}_{\text {leaf, max }}$ & PFT specific & $\operatorname{Pg}(\mathrm{N}) \mathrm{g}^{-1}(\mathrm{C})$ & maximum foliage nitrogen to carbon ratio & Zaehle and Friend (2010) \\
\hline $\mathrm{pc}_{\text {leaf, ave }}$ & PFT specific & $\mathrm{g}(\mathrm{P}) \mathrm{g}^{-1}(\mathrm{C})$ & average leaf phosphorus to carbon ratio & $\begin{array}{l}\text { Zaehle and Friend (2010) } \\
\text { McGroddy et al. (2004) }\end{array}$ \\
\hline$\tau_{i}$ & PFT specific & - & fraction of tissue $i$ shed per time step & Krinner et al. (2005) \\
\hline$f_{\text {trans }, i}$ & 0.57 & - & retranslocated fraction of tissue phosphorus & McGroddy et al. (2004) \\
\hline$\lambda_{i}$ & PFT and tissue specific & $\mathrm{g}(\mathrm{P}) \mathrm{g}^{-1}(\mathrm{C})$ & $\begin{array}{l}\text { phosphorus to carbon allocation to tissue } i ; i \in\{\text { root, sapwood }\} \\
\text { relative to leaves }\end{array}$ & $\begin{array}{l}\text { Sardans et al. (2015) } \\
\text { Sardans et al. (2015) }\end{array}$ \\
\hline$D_{\max }$ & 0.25 & - & $\begin{array}{l}\text { maximum change in phosphorus to nitrogen ratio of new biomass } \\
\text { relative to existing biomass }\end{array}$ & $\begin{array}{l}\text { Zaehle and Friend (2010) } \\
\text { Vuichard (unpublished data) }\end{array}$ \\
\hline$\tau_{\text {active, ref }}$ & 3.65 & $\mathrm{yr}^{-1}$ & $\begin{array}{l}\text { inverse of decomposition rate of phosphorus in } \\
\text { active soil organic matter pool due to biochemical mineralization }\end{array}$ & calibrated \\
\hline$\tau_{\text {slow, ref }}$ & 0.067 & $\mathrm{yr}^{-1}$ & $\begin{array}{l}\text { inverse of decomposition rate of phosphorus in } \\
\text { slow soil organic matter pool due to biochemical mineralization }\end{array}$ & calibrated \\
\hline$\tau_{\text {passive, ref }}$ & 0.0 & $\mathrm{yr}^{-1}$ & $\begin{array}{l}\text { inverse of decomposition rate of phosphorus in } \\
\text { passive soil organic matter pool due to biochemical mineralization }\end{array}$ & calibrated \\
\hline$k_{\mathrm{S}}$ & depends on soil order & - & fraction of labile phosphorus adsorbed & Yang and Post (2011) \\
\hline$\tau_{\text {sorb }}$ & 9125. & day $^{-1}$ & rate of strong sorption & this study \\
\hline$D_{0}$ & $1.581 \times 10^{-2}$ & $\mathrm{~m}^{2} \mathrm{t}^{-1}$ & phosphorus diffusion coefficient in free water at $25^{\circ} \mathrm{C}$ & Mollier et al. (2008) \\
\hline$c_{\Theta}$ & $1.0 \times 10^{-3}$ & - & unit conversion factor & this study \\
\hline$\Theta_{l}$ & 0.12 & $\mathrm{~m}^{3}\left(\mathrm{H}_{2} \mathrm{O}\right) \mathrm{m}^{-3}$ (soil) & soil water content at which the two functions intersect & Barraclough and Tinker (1981) \\
\hline$f_{1}$ & 1.58 & - & empirical factor & Barraclough and Tinker (1981) \\
\hline$f_{2}$ & -0.17 & - & empirical factor & Barraclough and Tinker (1981) \\
\hline$r_{\mathrm{d}}$ & $0.15 \times 10^{6}$ & $\mathrm{~g}(\mathrm{C}) \mathrm{m}^{-3}$ (root) & root-specific density & Bonan et al. (2014) \\
\hline$r_{\mathrm{r}}$ & $0.29 \times 10^{-3}$ & $\mathrm{~m}$ & root radius & Bonan et al. (2014) \\
\hline
\end{tabular}

in overall phosphorus uptake at high dissolved labile phosphorus concentration (low-affinity transporter) (Zhang et al., 2009) (Table 2). The values for the Michaelis-Menten constants are averages of the values reported in Schachtman et al. (1998) (page 448) for $k_{\mathrm{P}_{\min }}$ of the high-affinity system (Table 2). We initially used the values reported in Bouma et al. (2001) for $v_{\max }$ for orange trees, but had to reduce these values by a factor of 10 to achieve realistic uptake behavior (Table 2).

Plant uptake $\left(F_{\text {up }}\right)$ is derived from multiplying the root uptake capacity by the root carbon mass $\left(\mathrm{C}_{\text {root }}\right)$ and is scaled with $f \mathrm{PN}_{\text {plant }}$ to account for actual phosphorus demand and with $f_{\text {temp }}$ to avoid phosphorus accumulation in plants and soil at low temperature:

$F_{\text {up }}=u_{\text {max }} \mathrm{C}_{\text {root }} f \mathrm{PN}_{\text {plant }} f_{\text {temp }}$.

The temperature scaling function (Zaehle and Friend, 2010) is given by

$f_{\text {temp }}=\min \left(\exp \left(0.069 *\left(T_{\text {soil }}-T_{\text {soil, ref }}\right)\right), 1.0\right)$.

As phosphorus uptake is energetically costly (Schachtman et al., 1998), plant phosphorus uptake is down-regulated ac- cording to the $\mathrm{P}: \mathrm{N}$ ratio of plant tissue $\left(\mathrm{pn}_{\text {plant }}\right)$, avoiding excessive uptake of phosphorus (luxury consumption) when tissue phosphorus concentrations are at the prescribed maximum $\left(\mathrm{pn}_{\text {leaf, max }}\right)$ :

$\mathrm{pn}_{\text {plant }}=\frac{\mathrm{P}_{\text {labile }}+\mathrm{P}_{\text {leaf }}+\mathrm{P}_{\text {root }}}{\mathrm{N}_{\text {labile }}+\mathrm{N}_{\text {leaf }}+\mathrm{N}_{\text {root }}}$.

The dependency of phosphorus uptake on $\mathrm{pn}_{\text {plant }}$ is described as

$$
f \mathrm{PN}_{\text {plant }}=\min \left(\max \left(\frac{\mathrm{pn}_{\text {plant }}-\mathrm{pn}_{\text {leaf, max }}}{\mathrm{pn}_{\text {leaf, min }}-\mathrm{pn}_{\text {leaf, max }}}, 0.0\right), 1.0\right)
$$

where $\mathrm{pn}_{\text {leaf, min }}$ and $\mathrm{pn}_{\text {leaf, max }}$ are the minimum and maximum foliage $\mathrm{P}: \mathrm{N}$ ratios. Maximum uptake is reached when $\mathrm{pn}_{\text {plant }}$ equals $\mathrm{pn}_{\text {leaf, min }}$ by the use of a minimum function. Note that because neither the nitrogen nor the phosphorus concentration in the plant labile phosphorus pool $\left(\mathrm{P}_{\text {labile }}\right)$ is constrained by a prescribed $\mathrm{P}: \mathrm{N}$ ratio, the actual value of $f \mathrm{PN}_{\text {plant }}$ may be higher than 1 .

Further, we scale plant phosphorus uptake with a temperature function $\left(f_{\text {temp }}\right)$. We use the same equation as is used to 


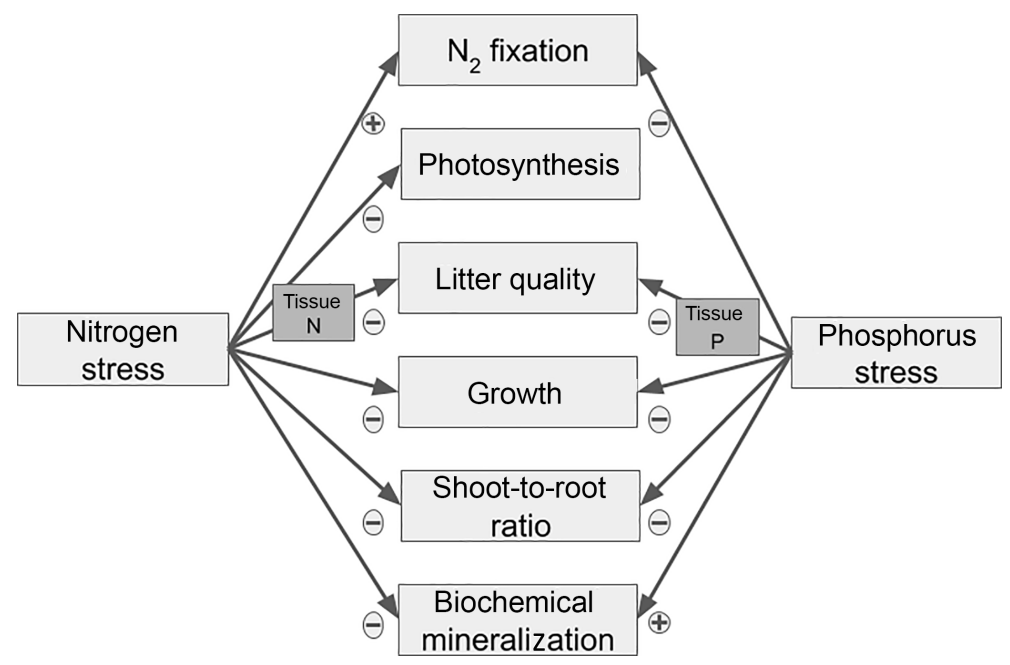

Figure 2. The effects of nitrogen and phosphorus stress (sub-optimal internal availability) on vegetation and associated processes in ORCHIDEE. A shortage of internal nutrients reduces tissue nutrient concentrations, overall growth (Eq. 12), the shoot-to-root ratio of new growth (Eq. 14), litter quality, and, in the case of nitrogen, the carboxylation efficiency of photosynthesis (Eq. 1). In addition, processes enhancing the availabilities of nitrogen and phosphorus are up-regulated (Eqs. 18 and B2).

scale soil carbon decomposition (Krinner et al., 2005), phosphorus mineralization, biochemical mineralization (Eq. 18), and nitrogen uptake and mineralization (Zaehle and Friend, 2010). The equation avoids the accumulation of phosphorus in plants or soils at low temperatures, mimicking the inhibition of biological processes when soils are frozen, which is not explicitly represented in ORCHIDEE.

The phosphorus taken up by plants enters their labile phosphorus pool $\left(\mathrm{P}_{\text {labile }}\right)$ whose dynamics are given by

$$
\frac{\mathrm{dP}_{\text {labile }}}{\mathrm{d} t}=F_{\text {up }}+\sum_{i=\text { leaf, root }} \tau_{i} f_{\text {trans }, i} \mathrm{P}_{i}-G_{\mathrm{P}}+F_{\text {reserve }}
$$

where $\tau_{i}$ is the fraction of foliage or roots shed each time step, $f_{\text {trans, } i}$ is the fraction of phosphorus recycled and transferred to plant labile phosphorus before tissue is shed, $G_{\mathrm{P}}$ is labile phosphorus allocated to new biomass, and $F_{\text {reserve }}$ is the flux to or from the long-term storage $\left(\mathrm{P}_{\text {reserve }}\right)$.

Following the dynamics of labile nitrogen (Zaehle and Friend, 2010), $P_{\text {labile }}$ is limited to a maximum size $P_{\text {labile, max }}$ which is taken as the phosphorus required to allocate the entire labile carbon pool according to the current growth rate and the maximum foliage phosphorus concentration. Any excess labile phosphorus is transferred to $P_{\text {reserve }}$ and is mobilized again if the size of the labile phosphorus pool falls below $\mathrm{P}_{\text {labile, max }}$ :

$F_{\text {reserve }}=\mathrm{P}_{\text {labile }}-\mathrm{P}_{\text {labile, } \max }$.

Following the assumption regarding nitrogen concentration (Zaehle and Friend, 2010), the phosphorus concentration in newly grown plant tissue is assumed to depend directly on the phosphorus concentration in the plant labile pool, providing a link between tissue activity and plant labile phosphorus availability. Foliage phosphorus concentration changes are simulated explicitly, with the phosphorus content of nonfoliage tissue varying in proportion to that of the foliage, as observed along gradients of soil fertility (Heineman et al., 2016). The phosphorus required $\left(G_{\mathrm{P}}\right)$ to sustain the current growth $\left(G_{\mathrm{C}}\right)$ of new tissue can therefore be written as

$$
\begin{aligned}
G_{\mathrm{P}}= & \left(\lambda_{\text {leaf }} f_{\text {leaf }}+\lambda_{\text {root }}\left(f_{\text {root }}+f_{\text {fruit }}\right)+f_{\text {sap }} \lambda_{\text {sap }}\right) \\
& \times\left(1+D_{\text {leaf }}\right) \mathrm{nc}_{\text {leaf }} \mathrm{pn}_{\text {leaf }} G_{\mathrm{C}},
\end{aligned}
$$

where $f_{i}$ are the fractions of carbon allocated to foliage $(i=$ leaf $)$, roots $(i=$ root $)$, fruits $(i=$ fruit $)$, and sapwood (stalks for grass) ( $i=$ sap) which are calculated dynamically (Zaehle and Friend, 2010; Naudts et al., 2015), nc leaf and $\mathrm{pn}_{\text {leaf }}$ are the nitrogen to carbon and the phosphorus to nitrogen ratio of current foliage, $\lambda_{i}$ are the phosphorus to carbon allocation to tissue $i$ relative to the phosphorus to carbon allocation to leaves $\left(\lambda_{\text {leaf }}=1\right)$, and $D_{\text {leaf }}$ is an empirical elasticity parameter.

Analogous to leaf nitrogen concentrations (Zaehle and Friend, 2010), the foliage phosphorus concentrations are dynamic state variables. If the plant labile phosphorus pool is not sufficient to maintain the current phosphorus concentration at the current carbon growth rate $G_{\mathrm{C}}$, the phosphorus concentration of newly grown leaf tissue is allowed to decrease relative to the concentration of existing foliage. Conversely, if plant labile phosphorus is larger than required, and the plant is not in the phase of flushing new foliage, $\mathrm{P}$ concentrations are allowed to increase.

To dampen day-to-day variations in tissue nutrient concentrations, such as at the beginning of the growing season, an empirical elasticity parameter ( $\left.D_{\text {leaf }}\right)$ is included. Meyerholt and Zaehle (2015) tested different assumptions about the stoichiometric flexibility in the OCN model and showed 
that stoichiometric flexibility is needed to reproduce observational data from fertilization experiments; however, they found that the original formulation in OCN was too flexible. Vuichard et al. (unpublished data) revised the formulation of the dampening equation for the leaf nitrogen concentration which is also applied for the leaf phosphorus concentration:

$$
\begin{aligned}
& D_{\text {leaf }}= \\
& \left\{\begin{array}{l}
D_{\max }\left(1-\exp \left[-\left(1.6 \frac{1 / \mathrm{pn}_{\text {leaf }}-1 / \mathrm{pn}_{\text {leaf, min }}}{1 / \mathrm{pn}_{\text {leaf, max }}-1 / \mathrm{pn}_{\text {leaf, min }}}\right)\right]\right) \\
\text { forP } P_{\text {labile }}<G_{\mathrm{P}} \\
D_{\max } \exp \left[-\left(1.6 \frac{1 / \mathrm{pn}_{\text {leaf }}-1 / \mathrm{pn}_{\text {leaf, min }}}{1 / \mathrm{pn}_{\text {leaf, max }}-1 / \mathrm{pn}_{\text {leaf, min }}}\right)\right] \\
\text { otherwise }
\end{array}\right.
\end{aligned}
$$

We adapted the dependency of biomass growth on plant labile nitrogen availability (Zaehle and Friend, 2010) for the dependency on plant labile phosphorus availability (Fig. 2): if the plant labile phosphorus concentration in vegetation fails to match the $\mathrm{P}$ requirement of biomass carbon growth, the growth of plant tissue is reduced proportionally to match phosphorus availability in the plant labile pool:

$p_{\text {lim }}=\min \left(1.0, \frac{g_{\text {max }} \mathrm{P}_{\text {labile }}}{G_{\mathrm{P}}}\right)$,

where $g_{\max }$ is a unit-less scalar regulating the maximal daily fraction of $\mathrm{P}_{\text {labile }}$ allocated to growth, to avoid a complete depletion of $\mathrm{P}_{\text {labile }}$ at any given time step. $g_{\max }$ is also used to regulate the allocatable fraction of labile carbon and labile nitrogen, and it is a function of temperature (Naudts et al., 2015). $G_{P}$ is the estimated amount of phosphorus needed to support growth.

C growth $\left(G_{\mathrm{C}}\right)$ is then scaled by the minimum of growth limitation factors derived from phosphorus availability $\left(p_{\text {lim }}\right)$ and nitrogen availability $\left(n_{\text {lim }}\right)$ (see Eq. 22 in the Supplement of Zaehle and Friend, 2010):

$G_{\mathrm{C}}=G_{\mathrm{C}} \min \left(p_{\lim }, n_{\lim }\right)$.

Nutrient stress in general affects the ratio leaf to root portioning of new growth:

$\mathrm{C}_{\text {leaf }}=n_{\text {scal }} f_{\mathrm{LF}} \mathrm{C}_{\text {root }}$,

where $f_{\mathrm{LF}}$ is a function relating leaf mass to root mass based on the pipe theory (Shinozaki et al., 1964) as originally implemented by Zaehle and Friend (2010) and recently updated by Naudts et al. (2015). $n_{\text {scal }}$ is the actual nutrient stress factor and is derived from the minimum of the nitrogen $\left(n_{\mathrm{scal}, \mathrm{N}}\right)$ and phosphorus $\left(n_{\text {scal,P }}\right)$ stress scaling factors:

$n_{\text {scal }}=\min \left(n_{\text {scal }, \mathrm{N}}, n_{\text {scal }, \mathrm{P}}\right)$.

$n_{\text {scal,P }}$ is given by the deviation of the actual plant phosphorus concentration from the maximal leaf phosphorus concentration relative to carbon concentration:

$n_{\text {scal }, \mathrm{P}}=\frac{\mathrm{pc}_{\text {plant }}}{\mathrm{pc}_{\text {leaf, ave }}}$, where $\mathrm{pc}_{\text {leaf, ave }}$ is the average of the maximum and minimum leaf phosphorus to carbon ratios $\left(\mathrm{pn}_{\text {leaf, min }}, \mathrm{pn}_{\text {leaf, max }}\right.$, $\mathrm{nc}_{\text {leaf, min }}$, and $\left.\mathrm{nc}_{\text {leaf, max }}\right)$ and $\mathrm{pc}_{\text {plant }}$ the growing season average of the plant labile phosphorus to labile carbon concentration:

$\mathrm{pc}_{\text {plant }}=\frac{\mathrm{P}_{\text {labile }}+\mathrm{P}_{\text {root }}+\mathrm{P}_{\text {leaf }}}{\mathrm{C}_{\text {labile }}+\mathrm{C}_{\text {root }}+\mathrm{C}_{\text {leaf }}}$.

The calculation of $n_{\text {scal,N }}$ follows the calculation of $n_{\text {scal,P }}$ with the exception that the deviation of the actual plant nitrogen concentration from the maximal leaf nitrogen concentration relative to carbon concentration is used (Zaehle and Friend, 2010).

Turnover of biomass phosphorus follows strictly the turnover of each biomass pool as described in Krinner et al. (2005). The phosphorus fluxes are derived from the carbon fluxes and the corresponding stoichiometric ratios, subtracting a fixed fraction of the phosphorus which is resorbed and added to the plant labile pool.

\subsubsection{Litter and soil organic matter}

The turnover of litter and soil organic matter follows the CENTURY model (Parton et al., 1993), which describes decomposition as a function of substrate availability, clay content, soil moisture, and soil temperature. Organic matter is separated into structural and metabolic litter and three soil organic matter pools (fast, slow, passive) which differ in their respective turnover times with no vertical discretization. Due to the fast turnover of microbial communities, microbial biomass is assumed to be always adjusted to the availability of labile organic matter and is thus part of the fast soil organic matter pool. The model is described in detail elsewhere (Krinner et al., 2005; Zaehle and Friend, 2010). The nitrogen concentrations of decomposing material are assumed to vary linearly with soil mineral nitrogen content. Instead of applying a comparable (empirical) approach for the phosphorus concentration of decomposing material (Parton et al., 1993; Kirschbaum et al., 2003), the phosphorus concentrations vary mechanistically as a function of biochemical mineralization (Eq. 18) (Wang et al., 2010; Goll et al., 2012; Yang et al., 2014).

\subsubsection{Biochemical mineralization}

Biochemical mineralization (phosphatase-mediated) decouples the mineralization of phosphorus partly from carbon decomposition and nitrogen mineralization (McGill and Cole, 1981). In contrast to biological mineralization of nitrogen and phosphorus, biochemical mineralization is not driven by the energy demand of microorganisms. Although phosphatase activity, which is a qualitative measure of biochemical mineralization, is common in soils (Stewart and Tiessen, 1987), the quantification of the mineralization rates in the field is not yet possible. 
We simulate biochemical (phosphatase-mediated) mineralization of phosphorus $\left(F_{\mathrm{bcm}}\right)$ with the aim to account for the observed increase in $F_{\mathrm{bcm}}$ when plants experience suboptimal P-to-N availabilities as an approximation of the stoichiometric status of the whole ecosystem (Margalef et al., 2017), including the effect of substrate availability on mineralization (McGill and Cole, 1981).

$F_{\mathrm{bcm}}=f \mathrm{PN}_{\text {plant }} f_{\text {temp }} \sum \tau_{x, \text { ref }} \mathrm{P}_{x}$,

where $\tau_{x, \text { ref }}$ is the turnover time of phosphorus in soil organic matter pool $x\left(\mathrm{P}_{x}\right)$ and the other two variables are scaling functions. First, biochemical mineralization is scaled according to the $\mathrm{P}: \mathrm{N}$ status of vegetation ( $\left.f \mathrm{PN}_{\text {plant }}\right)$ to account for the observed link between rizosphere phosphatase activity and plant nutritional status (Fox, 1992; Hofmann et al., 2016). Second, it is scaled with the same equation used to scale mineralization and root uptake according to soil temperature. The values of $\tau_{x, \text { ref }}$ are set arbitrarily, due to the lack of observational constraints, to half the turnover times used for the "biological mineralization" of organic matter (Krin-

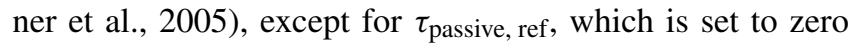
to account for inaccessible phosphorus in stabilized nutrientrich organic matter (Tipping et al., 2016).

\subsubsection{Soil mineral phosphorus}

The release of phosphorus from primary minerals is the primary source of phosphorus for many terrestrial ecosystems. In this study, we prescribed site-specific release rates $\left(F_{\text {weath }}\right)$, but a dynamic phosphorus weathering routine is implemented in ORCHIDEE which is described in the Appendix.

Leaching $\left(F_{\text {leach }}\right)$ of dissolved phosphorus $\left(\mathrm{P}_{\text {sol }}\right)$ occurs in proportion to the fraction of soil water $(\Theta)$ lost by the sum of simulated drainage and surface runoff $(q)$ :

$F_{\text {leach }}=\mathrm{P}_{\text {sol }} \frac{q}{\Theta}$.

We assume that at each time step a fixed fraction $\left(k_{\mathrm{s}}\right)$ of dissolved labile phosphorus is adsorbed onto soil particles and the remaining fraction $\left(1-k_{\mathrm{s}}\right)$ is dissolved. Instead of the commonly used Langmuir equation, we chose a linear approach for sorption, which works well for low soil phosphorus concentrations, which are common in most natural ecosystems (McGechan and Lewis, 2002). The calibration of the Langmuir equation for global application represents a major challenge as global datasets on soil phosphorus content are limited (Yang and Post, 2011) and parameters cannot be derived with enough confidence. Given the high sensitivity of the dynamics of available phosphorus on the sorption dynamics, we choose a simple but sufficiently constrainable approach. Thus the dynamics of sorbed labile phosphorus $\left(\mathrm{P}_{\text {sorb }}\right)$ are given by

$$
\frac{\mathrm{dP}_{\text {sorb }}}{\mathrm{d} t}=k_{\mathrm{s}} \frac{\mathrm{dP}_{\text {sol }}}{\mathrm{d} t} \text {. }
$$

The dynamics of dissolved labile phosphorus $\left(\mathrm{P}_{\text {sol }}\right)$ are given by (see Appendix A in Goll et al., 2012, for details)

$$
\begin{aligned}
\frac{\mathrm{dP}_{\mathrm{sol}}}{\mathrm{d} t} & =\left(1-k_{\mathrm{s}}\right)\left(F_{\text {weath }}-F_{\mathrm{up}}+F_{\mathrm{min}}+F_{\mathrm{bcm}}\right. \\
& \left.-\tau_{\mathrm{sorb}} \mathrm{P}_{\text {sorb }}-F_{\text {leach }}\right)
\end{aligned}
$$

where $F_{\text {weath }}$ (Eq. A1) is phosphorus release from primary minerals, $F_{\text {up }}$ (Eq. 4 ) is phosphorus uptake by plants, $F_{\text {bcm }}$ (Eq. 18) is biochemical mineralization, and $F_{\min }$ is the biological mineralization of phosphorus (Parton et al., 1993). The fraction of adsorbed to total soil labile phosphorus is derived from a global dataset of soil phosphorus fractions (Yang et al., 2013) and we use USDA soil-order-specific parameter values. Further, we assume a constant rate at which adsorbed mineral phosphorus becomes strongly sorbed $\left(\tau_{\text {sorb }}\right)$ and is subsequently fixed into secondary minerals. The turnover time of sorbed phosphorus with respect to occlusion is derived from the difference in occluded phosphorus among the sites of the Hawaii chronosequence (Violette, unublished data).

\subsubsection{Root zone mineral phosphorus}

As the mobility of phosphorus in soil is very low, plant uptake tends to be limited by the replenishment of phosphorus to the root surface rather than by the root uptake capacity itself (Schachtman et al., 1998). We simulate the labile phosphorus concentration in soil solution in root contact as a function of plant uptake and diffusion of phosphorus from the surroundings towards the root surface without a vertical discretization. We assume that plant uptake is small compared to the actual amount of dissolved phosphorus in total soil volume (Johnson et al., 2003), and thus its effect on the dissolved phosphorus concentration is limited to a small band around the surface of roots. The diffusion of phosphorus from the surroundings to the root surface $\left(F_{\text {diff }}\right)$ follows Fick's law:

$F_{\text {diff }}=-D \Delta \mathrm{P}_{\text {sol }}$,

where $D$ is the permeability of the soil to phosphorus and $\Delta \mathrm{P}_{\text {sol }}$ is the difference in the phosphorus concentrations between the soil solution at the root surface $\left(a_{\text {root }} \frac{\mathrm{P}_{\text {sol }}}{\Theta}\right)$ and the solution in the surrounding soil volume outside the diffusive zone around the $\operatorname{root}\left(\frac{\mathrm{P}_{\text {sol }}}{\Theta}\right)$. Assuming a homogeneous distribution of soil water, changes in the phosphorus concentration in the root zone are given by

$\Delta \mathrm{P}_{\text {sol }}=\left(a_{\text {root }}-1\right) \frac{\mathrm{P}_{\text {sol }}}{\Theta}$

where $\Theta$ is the volumetric soil water content and $a_{\text {root }}$ is the relative reduction of labile phosphorus in soil solution at the root surface compared to the surroundings. As $a_{\text {root }} \leq 1$, the diffusion is a single direction flux. 
The permeability $D$ is calculated analogously to the diffusion coefficient of phosphorus in soils following Barraclough and Tinker (1981), which accounts for the increased path length in soil using a tortuosity factor (tf). $D$ is further corrected for half the path length between uniform distributed root cylinders $\left(r_{\text {diff }}\right)$ :

$D=D_{0} c_{\Theta} \Theta \mathrm{tf} \frac{1}{r_{\mathrm{diff}}}$,

where $D_{0}$ is the diffusion coefficient in free water, $\Theta$ the volumetric soil water content, and $c_{\Theta}$ a unit conversion factor.

The tortuosity factor is given by a broken-line function of $\Theta$ (Barraclough and Tinker, 1981)

$\mathrm{tf}= \begin{cases}f_{1} \Theta+f_{2} & \text { for } \Theta \geq \Theta_{1} \\ \frac{\Theta\left(f_{1} \Theta+f_{2}\right)}{\Theta_{1}} & \text { otherwise }\end{cases}$

where $\Theta_{1}$ is the soil water content at which the two functions intersect, and $f_{1}$ and $f_{2}$ are empirical parameters (Barraclough and Tinker, 1981).

We assume that the diffusion path $\left(r_{\text {diff }}\right)$ can be approximated by half the distance between uniformly distributed roots. We restrict the diffusion path length to $0.1 \mathrm{~m}$, as the effect of active root phosphorus uptake on the soil phosphorus concentration at a distance of more than $10 \mathrm{~cm}$ is negligible (Li et al., 1991). Following Bonan et al. (2014), we derive half the distance between roots as

$r_{\text {diff }}=\min \left(0.1,(\pi \mathrm{RLD})^{0.5}\right)$

where the root length density (RLD) (root length per volume of soil) is given by

$\mathrm{RLD}=\frac{M_{\mathrm{root}}^{*}}{r_{\mathrm{d}} \pi r_{\mathrm{r}}^{2}}$

where $r_{\mathrm{d}}$ is the root-specific density and $\pi r_{\mathrm{r}}^{2}$ is the crosssectional area calculated from the fine root radius, $r_{\mathrm{r}}$, and $M_{\text {root }}^{*}$ is the root biomass density in the soil volume.

The change in the difference in the dissolved labile phosphorus concentration between the root surface and the surroundings, $a_{\text {root }}$, is then derived by

$\frac{\mathrm{d} a_{\text {root }}}{\mathrm{d} t}=\frac{F_{\text {diff }}-F_{\text {up }}}{\mathrm{P}_{\text {sol }}}$

where $F_{\text {up }}$ is plant uptake of phosphorus as described earlier.

\subsubsection{Competition between microbes and plants}

The competition between microbes and plants for dissolved labile phosphorus is handled analogously to the competition for soil mineral nitrogen (Zaehle and Friend, 2010). Gross phosphorus immobilization, gross biological phosphorus mineralization, biochemical mineralization, as well as plant phosphorus uptake are calculated half-hourly. At any time step, immobilization due to litter and soil organic matter decomposition is given priority in accessing nutrients from gross biological mineralization. This is in line with recent findings regarding the variability in the nitrogen use efficiency of microbes (Mooshammer et al., 2014), which indicates a dominance of microbes in accessing soil nitrogen and results in increasing immobilization with decreasing litter nutrient content.

The nutrient requirement for the build-up of soil organic matter, which affects the nutrients retained from litter decomposition, is dependent on the $\mathrm{C}: \mathrm{N}: \mathrm{P}$ ratio of soil organic matter, whereas the $\mathrm{C}: \mathrm{N}$ ratios depend on the soil mineral nitrogen concentration (Zaehle and Friend, 2010). Increasing plant uptake of nitrogen reduces the soil mineral nitrogen concentration and thereby reduces the nitrogen retained from litter decomposition in soil organic matter due to its effect on soil $\mathrm{C}: \mathrm{N}$ ratios.

\subsubsection{Input fields}

The parameter describing soil phosphorus sorption $\left(k_{\mathrm{s}}\right)$ is USDA soil order specific. The parameters for phosphorus release from minerals $\left(s_{\text {shield }}, w_{1}, E_{\mathrm{a}, 1}\right)$ are lithological class specific and read in from the GliM lithological map (Hartmann and Moosdorf, 2012).

\subsection{Site-scale simulation}

The long-term field fertilization experiment along the Hawaiian soil development chronosequence provides an ideal test case for the nutrient components of ORCHIDEE (Vitousek, 2004). We selected sites for which sufficient observational data are available (Harrington et al., 2001; Ostertag, 2001): a 300-year old site which is nitrogen limited (Thurston) and a $4.1 \mathrm{Myr}$ old site which is phosphorus limited (Kokee). The two sites have similar climatic conditions (Table 3) and are dominated by the same tree: Metrosideros polymorpha (Crews et al., 1995).

We run the model with observed meteorological data (Harris et al., 2014; Thornton et al., 2016) prescribing nutrient boundary conditions, namely inputs of phosphorus and nitrogen by atmospheric deposition (Chadwick et al., 1999) and inputs of phosphorus by weathering (Crews et al., 1995). To do so, we deactivated the module for dynamic phosphorus weathering (see the Appendix) and instead prescribed a constant site-specific release rate. In addition, we prescribe sitespecific physico-chemical soil properties (Crews et al., 1995; Chorover et al., 2004; Olander and Vitousek, 2004). The prescribed vegetation cover is tropical evergreen broadleaf vegetation.

We equilibrated the biogeochemical cycles of the $4.1 \mathrm{Myr}$ old site to the climatic conditions and the nutrient inputs using the semi-analytical spinup procedure (Naudts et al., 2015) which was extended to handle nutrient cycles. To cap- 
Table 3. The site conditions prescribed for the simulation for the 300-year old site and the 4.1 Myr old site along the Hawaii chronosequence.

\begin{tabular}{|c|c|c|c|}
\hline & Thurston & Kokee & Source \\
\hline latitude $\left({ }^{\circ} \mathrm{N}\right)$ & 19.4140 & 22.1390 & Vitousek (2004) \\
\hline longitude $\left({ }^{\circ} \mathrm{W}\right)$ & 155.2353 & 159.6245 & Vitousek (2004) \\
\hline altitude $(\mathrm{m})$ & 1176 & 1134 & Crews et al. (1995) \\
\hline age (years) & 300 & $4.1 \times 10^{6}$ & Vitousek (2004) \\
\hline mean annual temperature $\left({ }^{\circ} \mathrm{C}\right)$ & 16 & 16 & Crews et al. (1995) \\
\hline mean annual precipitation $\left(\mathrm{mm} \mathrm{yr}^{-1}\right)$ & 2500 & 2500 & Crews et al. (1995) \\
\hline $\mathrm{N}$ deposition $\left(\mathrm{g} \mathrm{m}^{-2} \mathrm{yr}^{-1}\right)$ & $0.6 \pm 0.4$ & $0.6 \pm 0.4$ & Chadwick et al. (1999) \\
\hline $\mathrm{P}$ deposition $\left(\mathrm{mg} \mathrm{m}^{-2} \mathrm{yr}^{-1}\right)$ & $0.9 \pm 0.3$ & $0.9 \pm 0.3$ & Chadwick et al. (1999) \\
\hline $\mathrm{P}$ release $\left(\mathrm{mg} \mathrm{m}^{-2} \mathrm{yr}^{-1}\right)$ & 434.0 & 0.265 & Violette (unpublished data) \\
\hline soil order & Entisols & Oxisols & Vitousek (2004) \\
\hline soil $\mathrm{pH}$ & 5.0 & 3.8 & Chorover et al. (2004) \\
\hline soil bulk density $\left(\mathrm{kg} \mathrm{m}^{-2}\right)$ & 300 & 575 & Olander and Vitousek (2004) \\
\hline soil texture (clay : silt : sand) $(\%)$ & $25: 25: 50$ & $17: 79: 4$ & Olander and Vitousek (2004) \\
\hline dissolved fraction labile $\mathrm{P}\left(1-k_{\mathrm{s}}\right)(\mathrm{)}$ & 0.4 & 0.2 & Violette (unpublished data) \\
\hline specific leaf area $\left(\mathrm{m}^{2} \mathrm{~g}^{-1}(\mathrm{C})\right)$ & $11.236 \times 10^{-3}$ & $11.236 \times 10^{-3}$ & Vitousek (2004) \\
\hline max. foliage $\mathrm{N}: \mathrm{P}$ ratio $\left(n p_{\text {leaf, } \max }\right)\left(\mathrm{g}(\mathrm{N}) \mathrm{g}^{-1}(\mathrm{P})\right)$ & 18.0 & 18.0 & Kattge et al. (2009) \\
\hline min. foliage $\mathrm{N}: \mathrm{P}$ ratio $\left(n p_{\text {leaf, } \min }\right)\left(\mathrm{g}(\mathrm{N}) \mathrm{g}^{-1}(\mathrm{P})\right)$ & 12.83 & 12.83 & Kattge et al. (2009) \\
\hline critical leaf age (yr) & 5.9 & 5.9 & Harrington et al. (2001) \\
\hline
\end{tabular}

ture the transitional nature of the 300-year old site, we perform a 230-year long spinup simulation. The differences between the simulation duration and the actual age of the site are due to a correction for an initial amount of biomass we have to set in ORCHIDEE for technical reasons (see Appendix $\mathrm{C}$ ).

We extended the spinup simulations of both sites into a set of three nutrient addition simulations: adding only nitrogen, only phosphorus, and nitrogen and phosphorus together. A total of $10 \mathrm{~g}(\mathrm{~N}) \mathrm{m}^{-2} \mathrm{yr}^{-1}$ and $10 \mathrm{~g}(\mathrm{P}) \mathrm{m}^{-2} \mathrm{yr}^{-1}$ are added in the model simulations homogeneously distributed across the year. In the field the same amount per year was applied, but semi-annually (Harrington et al., 2001; Ostertag, 2001).

\subsubsection{Forcing data}

The meteorological forcing data for ORCHIDEE are derived from Daily Surface Weather Data on a $1 \mathrm{~km}$ Grid for North America (DAYMET), version 3 (Thornton et al., 2016). The data include meteorological information (short-wave radiation, maximum daily temperature, minimum daily temperature, daily precipitation sum) for the period 1980-2013. In DAYMET, the mean annual surface temperature and annual sum of precipitation for the actual locations of the two sites (Table 3) substantially deviate from the values reported at the sites (Crews et al., 1995). Therefore, we pick the closest site nearby, Thurston $(16 \mathrm{~km}$ distance; lat $=19.8318$, lon $=-155.411)$, which has an annual sum of precipitation of $2500 \pm 250 \mathrm{~mm} \mathrm{yr}^{-1}$ and an average annual temperature $16 \pm 1{ }^{\circ} \mathrm{C}$ as reported in Crews et al. (1995), and use it for both sites (as the DAYMET data for the Kokee island did not include any grid point with an appropriate climate).
We extract additional information which is needed to run ORCHIDEE, namely surface pressure, long-wave downward radiation, and wind, from a $0.5 \times 0.5^{\circ}$ reanalysis dataset (CRU-NCEP) (Harris et al., 2014) using the coordinates of the Thurston site. We correct surface pressure from CRUNCEP with the actual altitude of each site using a lapse rate and derive specific humidity from water pressure, air temperature, and surface pressure.

The annual inputs of nutrients by atmospheric deposition and weathering (Table 3) are kept constant and are evenly distributed throughout the year.

\subsubsection{Site-specific parametrization}

We use site information collected from the literature (Harrington et al., 2001; Ostertag, 2001) to parametrize the model (Table 3). We account for differences in the soil characteristics between sites, but use a common parametrization for all biological processes. Thereby, we are able to evaluate the differences in vegetation due to differences in soil characteristics and chemical weathering solely.

As soils are not vertically discretized in ORCHIDEE, we average observations when given for different soil horizons. The soil fractions for Thurston are assumed to be $50 \%$ sand, $25 \%$ silt, and $25 \%$ clay due to a lack of site-specific information.

We account for changes in the sorption characteristics of volcanic soils as they develop. For the 300-year site, we use the average value of $k_{\mathrm{s}}$ for Andisols from Yang and Post (2011). For the $4.1 \mathrm{Myr}$ site $k_{\mathrm{s}}$ was scaled with the relative difference in soil phosphorus sorption capacity between the two sites as computed dynamically in the P-enabled ver- 
sion (Violette, unpublished data) of the WITCH mechanistic weathering model (Goddéris et al., 2006). P release rates from primary and secondary minerals are inferred from the observed differences in the chemical composition of minerals between sites along the chronosequence from Crews et al. (1995) (Violette, unpublished data).

The reference decomposition rates of soil organic matter pools by biochemical mineralization $\left(\tau_{x, \text { ref }}\right)$ are chosen so that the nitrogen to phosphorus ratio of soil organic matter is close to the observation of approximately $10 \mathrm{~g}(\mathrm{~N}) \mathrm{g}^{-1}((\mathrm{P})$ for sites older than $10 \mathrm{kyr}$ in the Hawaiian chronosequence (Crews et al., 1995). This is a common procedure (Wang et al., 2010; Goll et al., 2012; Yang et al., 2014) as this flux remains to be quantified in the field.

We prescribe observed values for specific leaf area, which is a fixed parameter and does not vary over time, and use the 25th and 75th percentiles of observed values of leaf $\mathrm{P}: \mathrm{N}$ of the dominant tree species (Kattge et al., 2011) as boundaries for the leaf $\mathrm{P}: \mathrm{N}$ ratio. We further increase the critical leaf age, which scales leaf turnover related to leaf age in ORCHIDEE, from 1.4 to 6 years to account for the substantially longer lifespan of leaves at both sites (Harrington et al., 2001) compared to the default value of ORCHIDEE (Naudts et al., 2015).

Following Yang et al. (2014), we adjust the turnover of the passive soil organic matter pools to achieve soil organic carbon stocks close to the observations. The same turnover rates are used for both sites.

The remaining parameters (including parameters for biological nitrogen fixation) are taken from the global parametrization of ORCHIDEE of the tropical evergreen broadleaf PFT (Table A1).

\subsubsection{Analysis}

We aggregate estimates of root production approximated by soil respiration from Ostertag (2001) and compare it to the simulated below-ground component of NPP (namely, NPP allocated to below-ground sapwood, below-ground heartwood, and fine roots). We sum the simulated above-ground component of NPP allocated to sapwood and heartwood and compare it to estimates of wood production based on wood increment and woody litter fall (Harrington et al., 2001). All other components of simulated NPP (fruit, leaf, reserve) are pooled and compared to estimates of non-woody NPP based on litterfall (Harrington et al., 2001). Simulated nutrient use efficiencies (NUE, PUE) are calculated as

$\mathrm{XUE}=\frac{\mathrm{NPP}}{X_{\text {uptake }}}$

where NPP is annual NPP and $X_{\text {uptake }}$ the annual uptake of nutrient $X, X \in\{\mathrm{N}, \mathrm{P}\}$. Simulated nutrient use efficiencies are then compared to estimates derived from on-leaf litter fall, root growth, and wood increment in combination with the chemical composition of leaves and wood (Harring- ton et al., 2001). We further separated the nutrient use efficiencies into its underlying components, carbon production rate per biomass nutrient $\left(X_{\text {prod }}\right)$ and nutrient residence time $\left(X_{\mathrm{MRT}}\right)$, following Finzi et al. (2007):

$$
\mathrm{XUE}=\underbrace{\frac{\mathrm{NPP}}{X_{\text {content }}}}_{X_{\text {prod }}} \times \underbrace{\frac{X_{\text {content }}}{X_{\text {uptake }}}}_{X_{\text {MRT }}},
$$

where $X_{\text {content }}$ is the whole plant content $\left(\mathrm{g}(\mathrm{X}) \mathrm{m}^{-2}\right)$ of nutrient $X, X \in\{\mathrm{N}, \mathrm{P}\}$. No information on below-ground productivity is available for the fertilization treatment (Harrington et al., 2001). Thus, we calculate above-ground nutrient use efficiencies ( $a$ NUE, $a$ PNUE) using above-ground NPP instead of total NPP.

Simulated apparent leaf lifespan (including climatic effects) is calculated by dividing the annual mean of leaf mass by the annual sum of NPP allocated to leaf growth. We calculate the rate by which soil organic phosphorus is biochemically mineralized and compare it to measurements of phosphatase activity (Olander and Vitousek, 2000) as a proxy of potential biochemical mineralization due to lack of alternatives.

The uncertainty ranges of simulated variables are given by the SD of annual values. We perform Student's $t$ tests to determine whether the fertilization treatments resulted in significant differences in the tested variables compared to the control experiment in observations (when sufficient information is available) and simulations.

\section{Results and discussion}

\subsection{Control simulation}

The comparison of carbon and nutrient cycle related ecosystem properties in the control simulations with observations allows us to detect model biases which facilitate the evaluation of the outcome of the fertilization experiments.

Net primary productivity (NPP) at both sites is well reproduced by the model (Fig. 3). At both sites NPP was not calibrated and thus is an independent model outcome. The simulated inter-annual variation in NPP at the $4.1 \mathrm{Myr}$ site is more than twice as large as at the 300-year site. The model tends to capture the allocation pattern of NPP to the different plant tissues (Table 4). While wood growth is overestimated at both sites, the relative allocation to leaf and roots is rather well reproduced: the simulated ratios between root and leaf growth of 1.35 and 1.50 for the 300-year and $4.1 \mathrm{Myr}$ sites, respectively, are close to the observed ratios of 1.36 and 1.33. This shows that the allocation scheme in ORCHIDEE, which accounts in a simplistic way for changes in the allocated fraction of NPP into below-ground allocation in response to stress (light, nutrient, water) (Zaehle and Friend, 2010; Naudts et al., 2015), gives reasonable results. 
Table 4. Vegetation characteristics at the 300-year old site and the 4.1 Myr old site along the Hawaii chronosequence under natural nutrient conditions (control simulation) (mean \pm SD). The observation based estimates (mean \pm SD) are from Crews et al. (2001), Harrington et al. (2001), and Ostertag (2001).

\begin{tabular}{|c|c|c|c|c|}
\hline & \multicolumn{2}{|c|}{ 300-year old site } & \multicolumn{2}{|c|}{ 4.1 Myr old site } \\
\hline & simulated & observed & simulated & observed \\
\hline $\mathrm{NPP}\left(\mathrm{g} \mathrm{m}^{-2} \mathrm{yr}^{-1}\right)$ & $758.0 \pm 347.0$ & $789.0 \pm 63.0$ & $816.0 \pm 503.0$ & $757 \pm 73$ \\
\hline $\mathrm{NPP}_{\text {leaf }}(\%)$ & 17.0 & 25.0 & 14.0 & 21.0 \\
\hline $\mathrm{NPP}_{\text {stem }}(\%)$ & 60.0 & 41.0 & 65.0 & 50.0 \\
\hline $\mathrm{NPP}_{\text {root }}(\%)$ & 23.0 & 34.0 & 21.0 & 28.0 \\
\hline $\operatorname{NUE}\left(g(C) g^{-1}(N)\right)$ & $165.7 \pm 303.5$ & $229.9 \pm 17.9$ & $115.8 \pm 89.7$ & $224.8 \pm 32.7$ \\
\hline $\mathrm{N}_{\mathrm{up}}\left(\mathrm{g}(\mathrm{N}) \mathrm{m}^{-2} \mathrm{yr}^{-1}\right)$ & $4.53 \pm 1.97$ & 3.43 & $7.04 \pm 5.46$ & 3.21 \\
\hline $\mathrm{N}_{\text {plant }}\left(\mathrm{g}(\mathrm{N}) \mathrm{m}^{-2}\right)$ & $39.1 \pm 1.95$ & $28.8^{\#}$ & $70.1 \pm 15.1$ & $28.8^{\#}$ \\
\hline $\mathrm{N}_{\text {prod }}\left(\mathrm{g}(\mathrm{C}) \mathrm{g}^{-1}(\mathrm{~N}) \mathrm{yr}^{-1}\right)$ & $19.2 \pm 4.8$ & 27.3 & $11.6 \pm 6.6$ & 25.0 \\
\hline $\mathrm{N}_{\mathrm{MRT}}(\mathrm{yr})$ & $8.6 \pm 94.6$ & 8.4 & $9.96 \pm 195.77$ & 9.0 \\
\hline PUE (g (C) mg $\left.{ }^{-1}(\mathrm{P})\right)$ & $2.67 \pm 0.61$ & $3.22 \pm 0.23$ & $1.89 \pm 2.53$ & $3.86 \pm 0.53$ \\
\hline $\mathrm{P}_{\mathrm{up}}\left(\mathrm{g}(\mathrm{P}) \mathrm{m}^{-2} \mathrm{yr}^{-1}\right)$ & $0.30 \pm 0.10$ & 0.24 & $0.43 \pm 0.32$ & 0.19 \\
\hline $\mathrm{P}_{\text {plant }}\left(\mathrm{g}(\mathrm{P}) \mathrm{m}^{-2}\right)$ & $2.60 \pm 0.08$ & $2.99^{\#}$ & $3.2 \pm 1.4$ & $2.99^{\#}$ \\
\hline $\mathrm{P}_{\text {prod }}\left(\mathrm{g}(\mathrm{C}) \mathrm{mg}^{-1}(\mathrm{P}) \mathrm{yr}^{-1}\right)$ & $0.29 \pm 0.07$ & 0.26 & $0.27 \pm 0.16$ & 0.24 \\
\hline $\mathrm{P}_{\mathrm{MRT}}(\mathrm{yr})$ & $9.3 \pm 4.3$ & 12.2 & $7.4 \pm 54.9$ & 16.0 \\
\hline biological nitrogen fixation $\left(\mathrm{g}(\mathrm{N}) \mathrm{yr}^{-1}\right)$ & $2.20 \pm .48$ & $2-3$ & $1.16 \pm 1.42$ & - \\
\hline leaf lifespan (yr) & $8.2 \pm 5.3$ & $8.2 \pm 1.8$ & $7.7 \pm 10.1$ & $3.6 \pm 0.6$ \\
\hline leaf nitrogen content (\% (dry weight)) & $0.93 \pm 0.04$ & $0.73 \pm 0.05$ & $1.12 \pm 0.30$ & $0.95 \pm 0.13$ \\
\hline leaf phosphorus content (\%o (dry weight)) & $0.61 \pm 1.99$ & $0.58 \pm 0.06$ & $0.64 \pm 0.03$ & $0.55 \pm 0.04$ \\
\hline leaf $\mathrm{N}$ : P ratio $\left(\mathrm{g}(\mathrm{N}) \mathrm{g}^{-1}(\mathrm{P})\right)$ & $15.2 \pm 1.1$ & $12.6 \pm 1.6$ & $17.5 \pm 0.03$ & $17.3 \pm 2.7$ \\
\hline $\mathrm{N}$ retranslocated $(\%)$ & $50^{*}$ & $41 \pm 12$ & $50^{*}$ & $55 \pm 6$ \\
\hline $\mathrm{P}$ retranslocated $(\%)$ & $57^{*}$ & $50 \pm 9$ & $57^{*}$ & $59 \pm 3$ \\
\hline labile $\mathrm{P}$ concentration $\left(\mathrm{mg}(\mathrm{P}) \mathrm{m}^{-2}\right)$ & $3.0 \pm 3.3$ & - & $1.17 \pm 0.88$ & - \\
\hline mineral $\mathrm{N}$ concentration $\left(\mathrm{g}(\mathrm{N}) \mathrm{m}^{-2}\right)$ & $0.04 \pm 0.02$ & - & $1.79 \pm 1.42$ & - \\
\hline
\end{tabular}

* Prescribed parameter. ${ }^{\#}$ From a nearby site. SD of observation only given when sufficient information is available in the original publication.

The simulated biomass stocks are in good agreement with the observations, with the exception of woody biomass at the 4.1 Myr site (Fig. 3). As wood growth is overestimated, the low woody biomass can be linked to an overestimation of wood turnover (Appendix D). Comparably, the slight overestimation of fine root biomass at the 300-year site is linked to an overly high turnover of fine roots (Appendix D). The large differences in observed fine root turnover between sites (Ostertag, 2001) cannot be captured by the model as fine root turnover is constant in ORCHIDEE.

Nutrient use efficiencies (NPP divided by plant nutrient uptake) are implicit plant properties that depend on the tissue stoichiometry, as well as the relative allocation of NPP to the various plant organs and their respective turnover rates. The nitrogen use efficiency (NUE) and phosphorus use efficiency (PUE) are underestimated between 20 and 50\% (Table 4). The analysis of the underlying components of nutrient use efficiencies following Finzi et al. (2007) (Eq. 30) indicates that the underestimation of NUE is mainly driven by the low carbon productivity per plant nitrogen $\left(\mathrm{N}_{\text {prod }}\right)$, while the low bias in PUE is due to a combination of low $\mathrm{P}_{\text {prod }}$ and the short residence time of plant phosphorus ( $\mathrm{P}_{\mathrm{MRT}}$ ) (Appendix D). The low $\mathrm{N}_{\text {prod }}$ and $\mathrm{P}_{\text {prod }}$ at the 300-year site can be attributed to the overestimation wood biomass and its nitrogen content (Appendix D). At the 4.1 Myr site the underestimation of the nutrient content of biomass and wood biomass has opposing effects on the nutrient use efficiencies. The general underestimation of the residence time of phosphorus (Table 4) is likely due to an underestimation of the phosphorus content of longlived plant tissue and the overestimation of wood turnover. Additionally, the extremely low concentration of plant available phosphorus at the $4.1 \mathrm{Myr}$ site results in a set of physiological and morphological adaptation mechanisms which increase $\mathrm{P}_{\mathrm{MRT}}$ but are not resolved in ORCHIDEE (for example, changes in root morphology and turnover and leaf phosphorus recycling) (Schachtman et al., 1998; Niu et al., 2013; Reed et al., 2015). In ORCHIDEE the somewhat longer nutrient residences times at the young site are primarily due to the site's transient state in which biomass is still accumulating (Appendix D).

The simulated inter-annual variabilities in nutrient use efficiencies, in particular in the simulated NUE at the 300year site, are very large due to a substantial but highly variable contribution of nutrients from internal reserves to new biomass growth (not shown). Reserves can amount to up to $75 \%$ of peak nutrient content in fine roots and leaves during 
(a) 300-year site

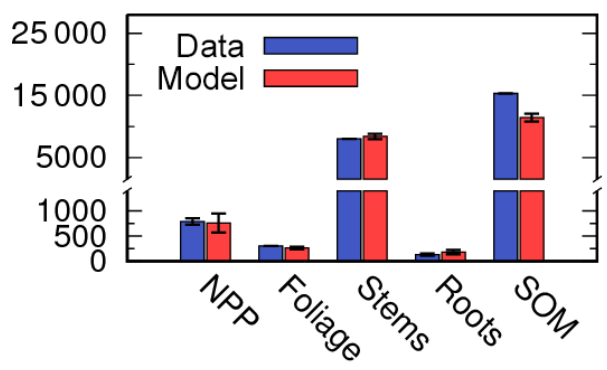

(b) 4.1 Myr site

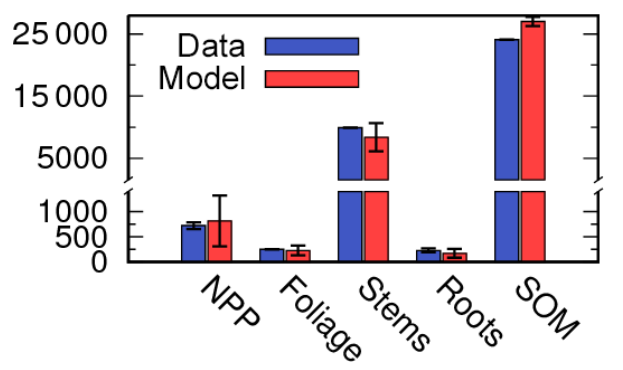

Figure 3. Comparison between simulations (mean $\pm \mathrm{SD}$ ) and observations (mean $\pm \mathrm{SD}$ - if available) at the 300-year old site (a) and the 4.1 Myr old site (b) along the Hawaii chronosequence. Net primary productivity (NPP) is given in $\mathrm{g}(\mathrm{C}) \mathrm{m}^{-2} \mathrm{yr}^{-1}$; the standing stocks of foliage, stems (including coarse roots), fine roots, and soil organic matter (SOM) are given in $\mathrm{g}(\mathrm{C}) \mathrm{m}^{-2}$. The SD in the case of simulations indicates the inter-annual variability, not model error.

the last growing season for evergreen plant functional types in ORCHIDEE (Zaehle and Friend, 2010). In the model, variations in reserves can be large in nutrient-poor environments which are subject to periods of reduced growth unrelated to nutrient starvation (here: drought). During droughts the nitrogen reserves are filled with foliage nitrogen which is recycled prior to leaf fall, while the nitrogen reserves are depleted when water availability and subsequent growth is high. Defoliation experiments indicate that plants can rely on substantial amounts of internally stored reserves of carbohydrate and nutrients which allow them to survive multiple defoliation events (Hartmann and Trumbore, 2016); however, the extent to which plants rely on internal storages is strongly species dependent (Piper and Fajardo, 2014), and the role of nutrients is often overlooked (Hartmann and Trumbore, 2016). Nonetheless, Ichie and Nakagawa (2013) showed that in Dryobalanops aromatica stored phosphorus accounted for $67.7 \%$ of the total phosphorus requirements for reproduction, while stored $\mathrm{N}$ accounted for only $19.7 \%$, indicating substantial nutrient reserves in tropical trees.

The simulated leaf $\mathrm{N}: \mathrm{P}$ ratio is, at 15.2 at the 300 -year site, somewhat higher than the observation of $12.6 \pm 1.56$, which lies just outside the lower boundary $\left(n p_{\text {leaf, } \min }\right)$ of 12.83 in ORCHIDEE (Table 4). At the $4.1 \mathrm{Myr}$ site, the simulated leaf $\mathrm{N}: \mathrm{P}$ ratio is at $17.5 \mathrm{~g}(\mathrm{~N}) \mathrm{g}^{-1}(\mathrm{P})$ very close to the observation of $17.3 \mathrm{~g}(\mathrm{~N}) \mathrm{g}^{-1}(\mathrm{P})$. Foliage $\mathrm{N}$ : P ratios of less than 14 are commonly associated with nitrogen limitation and ratios above 16 with phosphorus limitation (Koerselman and Meuleman, 1996). Although the simulated leaf nitrogen concentration of $0.93 \%$ (dryweight) at the 300 -year site is $27 \%$ higher than observed, it is substantially lower than the optimal concentration prescribed $\left(c n_{\text {leaf, min }}\right)$ of $3.33 \%$ dryweight, indicating substantial effects of the low soil nitrogen concentration (Table 4 ) on productivity and allocation at the 300-year site in the model. Thus, despite being useful tools, the common use of threshold stoichiometric ratios and models with rigid plant traits is somewhat limited when it comes to species-specific responses (Verheijen et al., 2016).

The differences in stoichiometry mirror differences in the respective availabilities of mineral nitrogen and soil labile phosphorus (Table 4). While the concentration of mineral nitrogen is extremely low at the young site due to a high immobilization demand of accumulating soil organic matter, the concentration is high at the old site, where immobilization demand is met by the mineralization of nitrogen from organic matter. In the case of phosphorus, the high phosphorus input of $434.0 \mathrm{mg} \mathrm{m}^{-2} \mathrm{yr}^{-1}$ at the 300 -year site keeps soil labile phosphorus concentration high despite the high immobilization demand. At the the old site, the extremely low phosphorus inputs of $0.27 \mathrm{mg} \mathrm{m}^{-2} \mathrm{yr}^{-1}$ result in low soil labile phosphorus concentration as the ecosystem relies primarily on the mineralization of phosphorus from soil organic matter.

At the 300 -year site, the simulated $\mathrm{C}: \mathrm{N}: \mathrm{P}$ stoichiometry of soil organic matter is at $309: 16: 1$ nearly twice as rich in phosphorus as observed $(425: 28: 1)$. As no significant differences in phosphatase activities among sites were observed (Ostertag, 2001) and the biochemical mineralization in ORCHIDEE is calibrated to achieve realistic phosphorus concentration in soil organic matter in the long term (4.1 Myr site), the deviation of the simulated from observed phosphorus concentrations has processes other than biochemical mineralization. A recent data analysis suggests that during initial stages of decomposition losses of carbon and phosphorus are proportional, but that there are smaller relative losses of nitrogen due to interactions between soil organic matter and the physical soil environment (Tipping et al., 2016). Reduced losses of nitrogen during initial stages of decomposition would lead to elevated $\mathrm{N}: \mathrm{P}$ during early stages of soil development compared to later stages. As the simplistic soil decomposition in ORCHIDEE (Parton et al., 1993) omits interactions between soil organic matter and the physical soil environment (Doetterl et al., 2015; Tipping et al., 2016), it fails to reproduce the strong influence of litter stoichiometry on the overall soil stoichiometry.

At the $4.1 \mathrm{Myr}$ site, the $\mathrm{C}: \mathrm{N}: \mathrm{P}$ stoichiometry of the soil organic matter is at $158: 12: 1$ relatively close to the observed $\mathrm{C}: \mathrm{N}: \mathrm{P}$ ratio of $215: 10: 1$. The realistic phosphorus content of soil organic matter indicates that the relative contribution of biochemical mineralization is sufficiently well 
calibrated in the model. It has to be noted that recent findings indicate a preferential physical stabilization of nutrientrich soil organic matter (Tipping et al., 2016) and a role of phosphatases in rendering organic compounds available as a carbon source to microbes (Spohn and Kuzyakov, 2013). Both findings challenge the classical view of a primary control of biochemical mineralization on the soil organic matter phosphorus concentration (Walker and Syers, 1976). Thus the common calibration approach (Wang et al., 2010; Goll et al., 2012; Yang et al., 2014) might be shortsighted.

The nitrogen fixation rate of $2.25 \pm 0.96 \mathrm{~g} \mathrm{~m}^{-2}$ at the 300 year site lies within the range observed among sites during early ( $<150$-year) soil development in Hawaii (Crews et al., 2001) (Table 4). The lower fixation rates at the 4.1 Myr site are due to the high mineral nitrogen availability. As the regulation mechanisms of nitrogen fixation are elusive (Barron et al., 2009; Vitousek et al., 2013) we only account for direct product inhibition control, a common regulation mechanism in biological systems, via soil mineral nitrogen concentrations (Eq. B2), omitting a direct influence of phosphorus availability on nitrogen fixation (Vitousek et al., 2013).

In summary, the model is able to capture biomass stocks and NPP well and - more importantly - captures the contrasting nutritional states of vegetation among the two sites, indicated by the foliage $\mathrm{N}: \mathrm{P}$ ratio. As we prescribe a common parametrization of vegetation characteristics for both sites, the differences in the leaf stoichiometry are the emergent outcome of the process governing the access of plants to nutrients and their response to two contrasting situations of nutrient availability which originate solely from differences in phosphorus inputs, labile phosphorus sorption capacity, and organic matter accumulation rate.

The model fails to reproduce differences in the allocation of NPP to different tissue and tissue turnover between sites, due to insufficient plasticity in tissue turnover and biomass allocation. The simulations suggest that the recycling and storage of nutrients in ecosystems subject to periods of drought or other nutrient-unrelated declines in foliage and growth are an important source of nutrients for new growth. We show that the approach of calibrating biochemical mineralization rates using the soil organic matter stoichiometry is problematic, which is in line with growing evidence of the physical stabilization of soil organic matter (Doetterl et al., 2015; Tipping et al., 2016) and new insights into the functioning of phosphatase (Spohn and Kuzyakov, 2013). We further show that despite ORCHIDEE's intended application when designed, the model is able to capture to a large degree the general state of an ecosystem in an early stage of soil development.

\subsection{Fertilization experiment}

To evaluate the simulated response of vegetation to nutrient addition, we perform three nutrient treatment simulations per site: addition of either nitrogen $(+\mathrm{N})$ or phosphorus $(+\mathrm{P})$, or (a) 300-year site

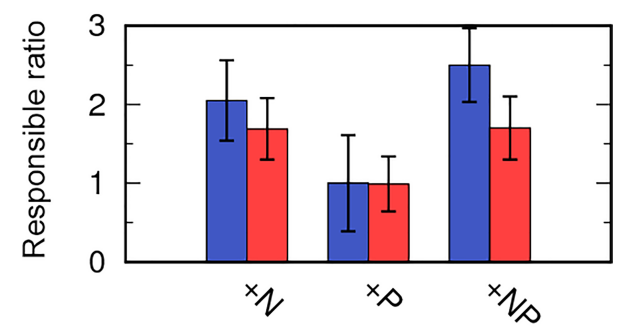

(b)

4.1 Myr site

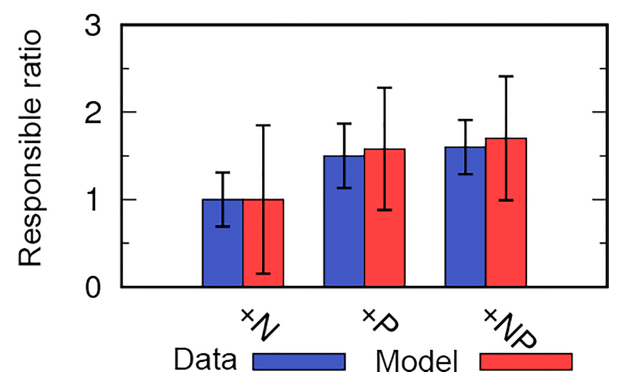

Figure 4. Comparison of simulated and observed responses of net primary production to fertilization at the 300-year old site (a) and the 4.1 Myr old site (b) along the Hawaii chronosequence. The response ratio is the measured or modeled plant production in the fertilizer treatment divided by its value under unfertilized conditions. The bars represent the measurement uncertainty and the annual variability in simulations, respectively.

the combined addition of both (+NP). The annual addition rates of nitrogen and phosphorus of $10 \mathrm{~g} \mathrm{~m}^{-2} \mathrm{yr}^{-1}$ are similar to the field experiments.

The model captures the signs of change in net primary productivity (NPP) to the fertilization treatments at both sites: at the 300-year site NPP strongly reacts to the addition of nitrogen, but not to the addition of phosphorus, while at the 4.1 Myr site NPP strongly reacts to the addition of phosphorus, but not to the addition of nitrogen (Fig. 4). For the 4.1 Myr site, the size of the simulated response ratio (defined as the NPP of the nutrient addition experiment divided by the NPP of the control experiment) is also comparable to the observed response ratio. At the 300-year site, the simulated positive effect of nitrogen deviates from the observation but is still within the range of uncertainty. However, the synergistic effects of combined addition are not captured by the model, as the model simulates a background phosphorus availability at the 300-year site which is high enough to support the nitrogen stimulated growth.

The 300-year site is accumulating organic material, in particular soil organic matter, and the accompanied immobilization of soil nutrients is the major driver of nutrient scarcity. This leads to extremely low mineral nitrogen concentration, whereas the high weathering release of phosphorus from minerals is sufficient to keep soil labile phosphorus concentration relatively high (Table 4). Therefore, vegetation reacts 
Table 5. The response of net primary productivity, leaf area index, nutrient use efficiencies, and foliar stoichiometry to nutrient addition at the 300-year old sites and the 4.1 Myr old site along the Hawaii chronosequence. Given are the relative difference between the nutrient addition experiments and the control simulation and, in parentheses, in the observed changes (Harrington et al., 2001; Ostertag, 2001). We used a Student's $t$ test to test whether nutrient addition resulted in a significant difference in the respective variables. If significant $(p>0.05)$, the values are in bold.

\begin{tabular}{|c|c|c|c|c|c|c|}
\hline & \multicolumn{3}{|c|}{ 300-year old site } & \multicolumn{3}{|c|}{ 4.1 Myr old site } \\
\hline & $+\mathrm{N}$ & $+\mathrm{P}$ & $+\mathrm{NP}$ & $+\mathrm{N}$ & $+\mathrm{P}$ & $+\mathrm{NP}$ \\
\hline NPP & $+69(+105) \%$ & $0(0) \%$ & $+70(+150) \%$ & $0(0) \%$ & $+\mathbf{5 8}(+\mathbf{5 0}) \%$ & $+70(+60) \%$ \\
\hline NPP/LA & $+44(+86) \%$ & $0(+72) \%$ & $+44(+128) \%$ & $-2(+41) \%$ & $+27(+32) \%$ & $+\mathbf{3 9}(+31) \%$ \\
\hline LAI & $+14(0) \%$ & $0(-13) \%$ & $+14(+30) \%$ & $+2(-11) \%$ & $+\mathbf{2 6}(+19) \%$ & $+18(+31) \%$ \\
\hline ANUE (ANPP/NUP) & $-38(+11) \%$ & $0(+32) \%$ & $-38(+12) \%$ & $-25(-10) \%$ & $-13(+30) \%$ & $-46(-20) \%$ \\
\hline APUE (ANPP/PUP) & $-\mathbf{3 5}(+33) \%$ & $-6(-45) \%$ & $-41(-35) \%$ & $0(+2) \%$ & $-13(-63) \%$ & $-68(-65) \%$ \\
\hline foliar $\mathrm{N}$ : P ratio & $+3(+25) \%$ & $-7(-45) \%$ & $-9(-20) \%$ & $0(-10) \%$ & $-23(-82) \%$ & $-23(-64) \%$ \\
\hline foliar $\mathrm{N}$ content & $+55(+16) \%$ & $0(-10) \%$ & $+\mathbf{5 5}(+7) \%$ & $+4(+11) \%$ & $+38(-14) \%$ & $+122(+22) \%$ \\
\hline foliar P content & $+51(-7) \%$ & $+8(+64) \%$ & $+70(+33) \%$ & $+4(+22) \%$ & $+88(+467) \%$ & $+187(+342) \%$ \\
\hline biochemical mineralization & $+92(+62) \%$ & $-52(-63) \%$ & $+9(-23) \%$ & $+22(+32) \%$ & $-91(-24) \%$ & $-90(-55) \%$ \\
\hline
\end{tabular}

strongly to the addition of nitrogen at the young site. The lack of any stimulation of plant productivity in the model to phosphorus addition at the young site indicates an overestimation of plant available phosphorus, likely due to the omission of differences in the occlusion rate of soil labile phosphorus among sites, which tends to be much higher at the young site (Violette, unpublished data). At the 4.1 Myr site the remobilization of phosphorus from soil organic matter is the major source of phosphorus for vegetation, as the minerals are phosphorus depleted, leading to low soil labile phosphorus concentration (Table 4). Compared to the young site, a higher fraction of soil labile phosphorus is also adsorbed to soil particles and is thus not available to plants. Therefore, vegetation reacts strongly to the addition of phosphorus at the old site, but not to nitrogen addition.

The increases in the NPP per leaf area (NPP/LA) are more pronounced than the increases in leaf area index when nitrogen stress is alleviated (300-year site), whereas the increases in NPP/LA are comparable to the increases in leaf area index when phosphorus stress is alleviated (4.1 Myr site) (Table 5), in both model and observations. Such a model behavior can be expected due to the lack of a direct effect of foliage phosphorus concentration on photosynthesis (Fig. 2). While the link between leaf nitrogen concentration and the carboxylation efficiency of photosynthesis $\left(V_{\mathrm{cmax}}\right)$ is well established (Kattge et al., 2009), the role of leaf phosphorus concentration in photosynthesis is less clear as nitrogen and phosphorus concentrations usually co-vary (Reich et al., 2009; Kattge et al., 2009; Domingues et al., 2010; Walker et al., 2014; Bahar et al., 2016; Norby et al., 2016).

The model fails to capture the drop in leaf area index when the non-limiting nutrient is added (which is phosphorus for the 300-year site and nitrogen for the 4.1 Myr site). The causes of the drop are unclear (Harrington et al., 2001), but could be related to an increase in grazing in the fertilized plots due to the higher nutrient content of foliage compared to the surroundings (Casotti and Bradley, 1991; Campo and Dirzo, 2003).

The model fails to capture the extent to which phosphorus use efficiency declines when phosphorus is added. This can be attributed to the omission of excessive plant uptake of nutrients (luxury consumption) which drives the observed reduction in the use efficiencies of the non-limiting nutrient (Harrington et al., 2001). As luxury consumption does not directly affect plant growth (Lawrence, 2001; Van Wijk et al., 2003) and is strongly species dependent (Lawrence, 2001), it is omitted in the model.

The model tends to overestimate increases in leaf nitrogen concentration in response to nitrogen addition, while increases in leaf phosphorus concentration in response to phosphorus addition are underestimated (Table 5). Biases in the availability of added nutrients to vegetation could be responsible for mismatch between observed and simulated responses. ORCHIDEE is prone to overestimating sorption losses when soil labile phosphorus concentration is substantially elevated above natural levels as the linear phosphorus sorption applied here cannot capture the increase in the dissolved fraction when the sorbed fraction approaches the maximum sorption capacity of the soil. The simulation setup of applying fertilizer evenly during the year, instead of in two fertilization events, underestimates nitrogen losses due to the nonlinear relationship between soil emissions and substrate availability (Shcherbak et al., 2014). However, the stoichiometric adjustments in ORCHIDEE are not process based and might be themselves the cause of the bias in the simulated response of leaf stoichiometry.

The sign of the responses of biochemical mineralization to nutrient addition mirrors the observed changes in potential phosphatase activity (Table 5). This indicates that the simplistic approach for biochemical mineralization applied in ORCHIDEE seems to capture the general behavior of phosphatase activity. However, it does not allow us to draw 
any conclusion about the overall significance of biochemical mineralization to total mineralization, which represents a major uncertainty for modeling phosphorus cycling (Goll et al., 2012; Yang et al., 2014; Reed et al., 2015).

In summary, the model is able to capture the contrasting responses to the three fertilization treatments among the two sites. We find further that differences between sites in the underlying changes in LAI and NPP/LA are partly captured by the model: the alleviation of nitrogen stress at the 300-year site increases NPP/LA more strongly than LAI, while the alleviation of phosphorus stress increases NPP/LA and LAI equally (Table 5). Nonetheless, the model underestimates the nitrogen limitation of productivity at the 300 -year site. The nitrogen capital of this site strongly depends on the nitrogen inputs and the efficiency at which nitrogen is retained in the ecosystem, which we could only roughly approximate.

\section{Conclusions}

Here, we present the implementation of a terrestrial phosphorus cycle and its interactions with the carbon and nitrogen cycle in the ORCHIDEE land surface model. The model accounts for effects of nutrient stress on tissue nutrient concentration, litter quality, root-to-shoot allocation, and photosynthesis. We further account for root phosphorus uptake and the movement of phosphorus in the soil volume as an additional constraint on soil phosphorus availability to plants, to reduce the sensitivity of plant phosphorus availability to the sorption dynamics which can only be poorly constrained from available data (Goll et al., 2012; Reed et al., 2015).

We evaluated the performance of the model at two sites of contrasting nutrient availabilities (Crews et al., 1995; Harrington et al., 2001; Ostertag, 2001). The model captures the different sensitivities of net primary productivity to nutrient addition among sites (Fig. 4). It further tends to reproduce differences in the leaf area index and leaf level productivity between the alleviation of nitrogen and phosphorus stress (Table 5). As we prescribed a common parametrization for all biological processes for both sites (Table 3), the contrasting response of vegetation to nutrient addition among sites is the emergent outcome of differences in the physico-chemical soil characteristics.
The model shows some deficiencies which can be linked to the lack of plasticity in the allocation of new growth to the different plant tissues and biomass turnover - a common issue in global models (De Kauwe et al., 2014). It further underestimates nutrient use efficiencies in general, primarily due to the overestimation of wood nutrient content and wood growth, but we cannot rule out that the nitrogen use efficiency of photosynthesis in ORCHIDEE which is derived from data of plants growing on a wide range of soil nutrient availability (Kattge et al., 2009) does not apply to the extreme environment found during early and late stages of soil formation.

Code availability. The ORCHIDEE model version used here is a development branch of ORCHIDEE, which is open source. The SVN version of the code branch is https://forge.ipsl.jussieu.fr/ orchidee/browser/branches/ORCHIDEE-CN-P revision 4520 from 21 July 2017. Please contact the corresponding author for the code of ORCHIDEE-CN-P if you plan an application of the model and envisage longer-term scientific collaboration.

Data availability. Primary data and scripts used in the analysis and other supplementary information that may be useful in reproducing the author's work can be obtained by contacting the corresponding author. 


\section{Appendix A: Phosphorus release by chemical weathering}

The release of phosphorus from minerals is the primary source of phosphorus for many terrestrial ecosystems. Besides prescribing release rates as done in this study, ORCHIDEE can simulate phosphorus release as a function of mineral phosphorus concentration, weatherability of minerals, intensity of the hydrological cycles, as well as temperature (Hartmann and Moosdorf, 2012; Goll et al., 2014). All additional variables and parameters are found in Tables A2 and $\mathrm{A} 3$. The release of phosphorus from minerals is given by

$$
F_{\text {weath }}=s_{\text {shield }} \sum_{l=1, n l} f_{\text {tweath, } 1} w_{1} a_{1} q_{\text {ann }}
$$

where $s_{\text {shield }}$ is a scaling factor down-regulating release rates for soils where the active zone is disconnected from the bedrock, $f_{\text {tweath, } 1}$ links the weathering reaction to temperature, $w_{1}$ is an empirical parameter describing the $\mathrm{P}$ content and erodibility of lithological class $l, a_{1}$ is the fraction of the grid box occupied by lithological class $l$, and $q_{\text {ann }}$ is a running average of the sum of drainage and surface runoff of the last 12 months.

The temperature dependence of weathering is described by an Arrhenius term (Hartmann et al., 2014): $f_{\text {weath, } 1}=e^{\left(\frac{-E_{\mathrm{a}, 1}}{R}\right)\left(\frac{1}{T_{2 \mathrm{~m}}-\frac{1}{T_{\text {ref }}}}\right)}$,

where $E_{\mathrm{a}, 1}$ is the activation energy of the reaction for lithological class $l, R$ is the gas constant, $T_{2 \mathrm{~m}}$ the long-term (3month) average of $2 \mathrm{~m}$ air temperature, and $T_{\text {ref }}$ the reference temperature.

This approach accounts for the hydrological constraint on the dissolution reaction by the removal of products as well as for the energetic constraints of the reaction itself (Hartmann et al., 2014). We take full advantage of the high resolution of the lithological data (Hartmann and Moosdorf, 2012) by assigning each ORCHIDEE grid box the fractional coverage of the 16 lithological classes, thereby accounting for sub-grid-scale heterogeneity in lithology. Following Goll et al. (2014), we use 3-month running averages of the climatic drivers $\left(q_{\mathrm{ann}}, T_{2 \mathrm{~m}}\right)$. On that timescale, the soil temperature follows the $2 \mathrm{~m}$ air temperature in most regions of the globe. This allows us to keep the original formulation which is based on air temperature. In soils where the active zone is disconnected from the bedrock the phosphorus release is down-regulated by a soil shielding factor $\left(s_{1}\right)$ which is read in from a global map (Hartmann et al., 2014). 
Table A1. Plant functional type (PFT) specific parameters: tropical evergreen broadleaf forest (TrEBF), tropical raingreen broadleaf forest (TrDBF), temperate evergreen needleleaf forest (TeENF), temperate evergreen broadleaf forest (TeEBF), temperate summergreen broadleaf forest (TeDBF), boreal evergreen needleleaf forest (BoENF), boreal summergreen broadleaf forest (BoDBF), boreal summergreen needleleaf forest (BoDNF), C3 grassland (C3grass), and C4 grassland (C4grass).

\begin{tabular}{|c|c|c|c|c|c|c|c|c|c|c|c|}
\hline & TrEBF & $\operatorname{TrDBF}$ & TeENF & TeEBF & TeDBF & BoENF & BoDBF & BoDNF & C3grass & C4grass & Source \\
\hline nue $\left(\mu \mathrm{mol}\left(\mathrm{CO}_{2}\right) \mathrm{g}^{-1}(\mathrm{~N}) \mathrm{s}^{-1}\right)$ & 22.0 & 22.0 & 20.0 & 33.0 & 33.0 & 20.0 & 33.0 & 22.0 & 45.0 & 45.0 & Kattge et al. (2009) \\
\hline$c n_{\text {leaf, } \min }\left(\mathrm{g}(\mathrm{C}) \mathrm{g}^{-1}(\mathrm{~N})\right)$ & 16.0 & 16.0 & 28.0 & 16.0 & 16.0 & 28.0 & 16.0 & 16.0 & 16.0 & 16.0 & Zaehle and Friend (2010) \\
\hline$c n_{\text {leaf, } \max }\left(\mathrm{g}(\mathrm{C}) \mathrm{g}^{-1}(\mathrm{~N})\right)$ & 60.0 & 60.0 & 75.0 & 45.0 & 45.0 & 75.0 & 45.0 & 45.0 & 45.0 & 45.0 & Zaehle and Friend (2010) \\
\hline$n p_{\text {leaf, } \min }\left(\mathrm{g}(\mathrm{N}) \mathrm{g}^{-1}(\mathrm{P})\right)$ & 16.68 & 16.68 & 8.34 & 10.84 & 10.84 & 8.34 & 10.84 & 10.84 & 10.84 & 10.84 & McGroddy et al. (2004) \\
\hline$n p_{\text {leaf, } \max }\left(\mathrm{g}(\mathrm{N}) \mathrm{g}^{-1}(\mathrm{P})\right)$ & 22.57 & 22.57 & 11.29 & 14.67 & 14.67 & 11.29 & 14.67 & 14.67 & 14.67 & 14.67 & McGroddy et al. (2004) \\
\hline$\lambda_{\text {root }}\left(\mathrm{g}(\mathrm{P}) \mathrm{g}^{-1}(\mathrm{P})\right)$ & 1.0 & 1.0 & 1.0 & 1.0 & 1.0 & 1.0 & 1.0 & 1.0 & 1.0 & 1.0 & Wang et al. (2010) \\
\hline$\lambda_{\text {sapwood }}\left(\mathrm{g}(\mathrm{P}) \mathrm{g}^{-1}(\mathrm{P})\right)$ & 0.087 & 0.087 & 0.087 & 0.087 & 0.087 & 0.087 & 0.087 & 0.087 & 0.087 & 0.087 & $\begin{array}{l}\text { McGroddy et al. (2004); } \\
\text { Sardans et al. (2015) }\end{array}$ \\
\hline
\end{tabular}

Table A2. Parameters of the dynamical weathering routine.

\begin{tabular}{lllll}
\hline Parameter & Value & Units & Description & Source \\
\hline$s_{\text {shield }}$ & depends on location & - & soil shielding factor & Hartmann et al. (2014) \\
$w_{1}$ & depends on location & $\mathrm{g}(\mathrm{P}) \mathrm{mm}$ & empirical factor & Hartmann et al. (2014) \\
$a_{1}$ & depends on location & - & fraction of grid box occupied by lithology $l$ & Hartmann and Moosdorf (2012) \\
$E_{\mathrm{a}, 1}$ & depends on lithology & $\mathrm{J}$ & activation energy for lithological class $l$ & Hartmann et al. (2014) \\
$R$ & 8.3144598 & $\mathrm{~J} \mathrm{~mol}{ }^{-1} \mathrm{~K}^{-1}$ & gas constant & Hartmann et al. (2014) \\
$T_{\text {ref }}$ & 284.15 & $\mathrm{~K}$ & reference temperature & \\
\hline
\end{tabular}

Table A3. Additional variables of the dynamical weathering routine.

\begin{tabular}{lll}
\hline Variable & Units & Description \\
\hline$f_{\text {tweath, } 1}$ & - & temperature dependence of weathering \\
$q_{\text {ann }}$ & $\mathrm{mm} \mathrm{yr}^{-1}$ & annual sum of runoff and drainage \\
$T_{2 \mathrm{~m}}$ & $\mathrm{~K}$ & 2 m air temperature \\
$q$ & $\mathrm{~mm} \mathrm{t}^{-1}$ & sum of runoff and drainage \\
\hline
\end{tabular}

Table A4. The bias (simulated-observed) in carbon production per biomass nutrient $\left(\mathrm{N}_{\text {prod }}, \mathrm{P}_{\text {prod }}\right)$. From simulations (default) and as diagnosed by substituting simulated with observed nutrient content (observed $x c_{i}$ ) and/or biomass stocks (observed $\mathrm{C}_{i}$ ).

\begin{tabular}{lrrrr}
\hline & \multicolumn{2}{c}{$\mathrm{N}_{\text {prod }}(\%)$} & \multicolumn{2}{c}{$\mathrm{P}_{\text {prod }}(\%)$} \\
\cline { 2 - 5 } & 300-year & $4.1 \mathrm{Myr}$ & 300 -year & $4.1 \mathrm{Myr}$ \\
\hline default & -59.4 & -44.7 & -20.0 & +23.6 \\
observed $x c_{i}$ & -30.0 & +33.2 & -30.5 & +26.2 \\
observed $\mathrm{C}_{i}$ & -39.0 & -62.9 & -16.7 & -25.6 \\
observed $\mathrm{C}_{i} \& x c_{i}$ & -0.6 & -1.7 & -0.6 & -1.7 \\
\hline
\end{tabular}


Table A5. The overall residence times of carbon $\left(\mathrm{C}_{\mathrm{MRT}}\right)$, nitrogen $\left(\mathrm{N}_{\mathrm{MRT}}\right)$, and phosphorus $\left(\mathrm{P}_{\mathrm{MRT}}\right)$ in biomass (excluding storage), as well as the approximated residence time of all elements $(\mathrm{C}, \mathrm{N}, \mathrm{P})$ in foliage $\left(X_{\mathrm{MRT}}\right.$,leaf $)$, coarse roots, and stems $\left(X_{\mathrm{MRT}}\right.$,wood $)$, as well as fine roots $\left(X_{\text {MRT,root }}\right)$. The latter three tissue classes consist of tissue with similar stoichiometry and thus the residence time of all elements is the same.

\begin{tabular}{lrrrr}
\hline & \multicolumn{2}{c}{300 -year } & \multicolumn{2}{c}{$4.1 \mathrm{Myr}$} \\
\cline { 2 - 5 } & simulated & observed & simulated & observed \\
\hline $\mathrm{C}_{\text {MRT }}$ (yr) & 12.5 & 10.7 & 9.5 & 14.4 \\
$\mathrm{~N}_{\text {MRT }}$ (yr) & 9.5 & 8.4 & 8.4 & 9.0 \\
P $_{\text {MRT (yr) }}$ & 9.6 & 12.2 & 7.3 & 16.0 \\
$X_{\text {MRT,leaf }}(\mathrm{yr})$ & 2.1 & 1.6 & 1.8 & 1.6 \\
$X_{\text {MRT,root }}(\mathrm{yr})$ & 6.3 & 1.5 & 5.6 & 10.6 \\
$X_{\text {MRT,wood }}(\mathrm{yr})$ & 14.7 & 16.3 & 11. & 18.1 \\
\hline
\end{tabular}




\section{Appendix B: Biological nitrogen fixation}

While inputs of nitrogen from nitrogen-rich sedimentary rocks can make a significant contribution to the nitrogen budget of specific sites (Holloway, 2002; Morford et al., 2011), the major natural inputs are from biological fixation of atmospheric dinitrogen which is in ample supply (Vitousek et al., 2013). Biological nitrogen fixation (BNF) represents a key process which can enhance nitrogen availability under elevated $\mathrm{CO}_{2}$. Here we use a commonly used representation of $\mathrm{BNF}$ which is derived from an empirical correlation between BNF $\left(F_{\mathrm{BNF}}\right)$ and evapotranspiration (ET) (Cleveland et al., 1999 ) in which ET is substituted with NPP as they are highly correlated (Thornton et al., 2007):

$F_{\mathrm{BNF}}=\alpha_{\mathrm{bnf}}\left(1-e^{\beta_{\mathrm{BNF}} \mathrm{NPP}_{\mathrm{ann}}}\right)$,

where $\beta_{\mathrm{BNF}}=-3 \times 10^{-3} \mathrm{yrg}^{-1}(\mathrm{C})$ is an empirical coefficient (Cleveland et al., 1999) and $\alpha_{\mathrm{bnf}}=0.967 \mathrm{~g}(\mathrm{~N}) \mathrm{yr}^{-1}$ was chosen such that the global rate of BNF is close to an estimate of $58 \mathrm{Tg}(\mathrm{N}) \mathrm{yr}^{-1}$ (Vitousek et al., 2013) for a NPP of $60 \mathrm{Pg}(\mathrm{C}) \mathrm{yr}^{-1}$. We introduced a scaling function $f_{\mathrm{Nmin}}$ to avoid unrealistic increases in BNF due to increases in NPP in case soil mineral nitrogen is in ample supply (Thomas et al., 2013).

$F_{\mathrm{BNF}}=c_{\mathrm{bnf}} \alpha_{\mathrm{bnf}}\left(1-e^{\beta_{\mathrm{BNF}} \mathrm{NPP}_{\mathrm{ann}}}\right) f_{\mathrm{Nmin}}$,

where $c_{\mathrm{bnf}}=57.039 \times 10^{-6}$ is a factor to convert from the annual flux to a flux per time step, and $\mathrm{NPP}_{\mathrm{ann}}$ is the running average of the sum of net primary productivity during the last 12 months.

The scaling function $f_{\mathrm{Nmin}}$ is from Zaehle and Friend (2010), where it is used to scale soil organic matter nitrogen content and is given by

$f_{\mathrm{Nmin}}= \begin{cases}\left(\frac{n_{\text {th }}-\left(\mathrm{N}_{\mathrm{NH}_{4}}+\mathrm{N}_{\mathrm{NO}_{3}}\right)}{n_{\mathrm{th}}}\right) & \text { for }\left(\mathrm{N}_{\mathrm{NH}_{4}}+\mathrm{N}_{\mathrm{NO}_{3}}\right)<n_{\text {th }} \\ 0.0 & \text { otherwise }\end{cases}$

where $n_{\text {th }}$ is a threshold of $2 \mathrm{~g}(\mathrm{~N}) \mathrm{m}^{-2}$ and $\mathrm{N}_{\mathrm{NH}_{4}}$ and $\mathrm{N}_{\mathrm{NO}_{3}}$ are the respective concentrations of ammonia and of nitrate in the soil.

\section{Appendix C: Length correction for the spinup simulation of the 300-year old site}

The 300-year old site is characterized by low nitrogen availability due to the short period over which nitrogen could have accumulated via biological fixation and atmospheric deposition (Crews et al., 1995). In ORCHIDEE vegetation has to be initialized with a minimum amount of biomass corresponding to a land cover with trees of an age between 2 and 3 years (Naudts et al., 2015). The litter and soil organic matter pools are set to a negligible initial value. The minimum biomass corresponds to a substantial amount of total ecosystem nitrogen $\left(\mathrm{N}_{\text {tot }}(0)\right)$ of $20.8 \mathrm{~g}(\mathrm{~N}) \mathrm{m}^{-2}$ being present at the end of the first year. Therefore, we reduce the duration of the spinup simulation to compensate for the initial nitrogen stock.

To do so, we perform a 300-year long simulation and estimate the fraction of nitrogen from biological nitrogen fixation and atmospheric deposition which is retained in the ecosystem $\left(f_{\mathrm{r}}\right)$ :

$f_{\mathrm{r}}(t)=\frac{\Delta \mathrm{N}_{\mathrm{tot}}(t)}{\mathrm{BNF}(t)+\mathrm{DEP}_{\mathrm{obs}}}$,

where $\Delta \mathrm{N}_{\text {tot }}(t)$ is the simulated annual change in $\mathrm{N}_{\text {tot }}$, $\mathrm{BNF}(t)$ is simulated annual flux of biological nitrogen, and $\mathrm{DEP}_{\mathrm{obs}}$ the annual flux of deposition (forcing) of year $t$. We find that, besides during the first 40 years, the $\overline{f_{\mathrm{r}}}$ is at $0.11 \pm 0.04$ (average $\pm \mathrm{SD}$ ) relatively constant. In combination with estimates of nitrogen fixation (BNF; $\mathrm{g} \mathrm{m}^{-2} \mathrm{yr}^{-1}$ ) and atmospheric deposition (DEP; $\mathrm{g} \mathrm{m}^{-2} \mathrm{yr}^{-1}$ ) the time (a) which would have been needed to accumulate the initial stock can be approximated by

$a=\frac{\mathrm{N}_{\mathrm{tot}}(t=0)}{\overline{f_{\mathrm{r}}}\left(\mathrm{BNF}_{\mathrm{obs}}+\mathrm{DEP}_{\mathrm{obs}}\right)}$.

The observed rates of nitrogen fixation $\left(\mathrm{BNF}_{\mathrm{obs}}\right)$ during the first 150 year of soil development in Hawaii are rather stable (2.0-3.1 $\mathrm{g}(\mathrm{N}) \mathrm{m}^{-2} \mathrm{yr}^{-1}$ ) (Crews et al., 2001), Estimates for atmospheric deposition $\left(\mathrm{DEP}_{\mathrm{obs}}\right)$ are $0.6 \pm$ $0.4 \mathrm{~g}(\mathrm{~N}) \mathrm{m}^{-2} \mathrm{yr}^{-1}$ (Chadwick et al., 1999).

Depending on $f_{\mathrm{r}}, 45-95$ years would have passed before $20.8 \mathrm{~g}(\mathrm{~N}) \mathrm{m}^{-2}$ could have accumulated. We therefore reduced the simulations' duration from 300 to 230 years.

As the simulated NPP, biomass, and soil organic matter match the observation (Table 4) and the dynamically simulated BNF rates are with $2.25 \mathrm{~g}(\mathrm{~N}) \mathrm{m}^{-2} \mathrm{yr}^{-1}$ well within the observed range, the reduction of the simulation length seems appropriate.

\section{Appendix D: Analysis of biases in carbon production rate per biomass nutrient}

Here we investigate the cause of the model biases in carbon productivity of nutrient $x\left(X_{\text {prod }}\right)$. All calculation are done with the long-term averages of the simulated variables and not with the annual fluxes like done in the main analysis. Thus the values might deviate slightly from the ones reported earlier. By substituting $\mathrm{N}_{\text {content }}$ in Eq. (30) with the carbon mass of tissue $i$ and the respective $x: c$ ratios $\left(x c_{i}\right)$ we can investigate the contribution of the respective components of $X_{\text {prod }}$ to the overall bias in $X_{\text {prod: }}$ :

$X_{\text {prod }}=\frac{\mathrm{NPP}}{\sum \mathrm{C}_{i} x c_{i}}$.

To calculate the contribution of the bias in $\mathrm{nc}_{i}$ to the bias in $\mathrm{N}_{\text {prod }}$, we used simulated $\mathrm{nc}_{i}$ but NPP and $\mathrm{C}_{i}$ from the observation in Eq. (D1). 
We find that at both sites the underestimations of $\mathrm{N}_{\text {prod }}$ of -59.4 and $-44.7 \%$ are related to the overestimation of tissue nitrogen content (see "observed $\mathrm{C}_{i}$ " in Table A4). The effect of biases in simulated biomass on $\mathrm{N}_{\text {prod }}$ differs between sites, as biomass stocks, and subsequently nitrogen stocks, are underestimated at the 300-year site, while they are overestimated at the 4.1 Myr site (Fig. 3). When biomass and nitrogen content are taken from observation, the bias in $\mathrm{N}_{\text {prod }}$ is in general low due to the good agreement of simulated and observed NPP (Fig. 3).

The effects of biases in $x c_{i}$ and/or $\mathrm{C}_{i}$ on $\mathrm{P}_{\text {prod }}$ are comparable to their effects on $\mathrm{N}_{\text {prod }}$ at both sites.

We calculated the residence time of nutrients $\left(X_{\mathrm{MRT}, i}\right)$ for classes of tissues sharing similar stoichiometry in ORCHIDEE, namely leaf, coarse root and stems, and fine roots:

$X_{\mathrm{MRT}, i}=\frac{\mathrm{C}_{i} x c_{i}}{\mathrm{NPP}_{i} x c_{i}}$,

where $\mathrm{NPP}_{i}$ is the fraction of NPP being allocated to tissue class $i$. The equation can be simplified to
$X_{\mathrm{MRT}, i}=\frac{\mathrm{C}_{i}}{\mathrm{NPP}_{i}}$

showing that the residence time $X_{\mathrm{MRT}, i}$ is equal to the residence time of carbon. Table A5 shows the residence times of the different tissue classes as well as $\mathrm{C}_{\mathrm{MRT}}, \mathrm{N}_{\mathrm{MRT}}$, and $\mathrm{P}_{\mathrm{MRT}}$ calculated as described in the method section of the main paper.

The observed residence times of carbon, nitrogen, and phosphorus (Table A5) are longer at the 4.1 Myr site than they are at the 300-year site, whereas the model simulates an opposite pattern. As the constant tissue turnover rates are used in ORCHIDEE, the model is not able to reproduce differences among sites. The slightly longer residence times at the young site can be attributed to the transient state of vegetation in which it is still accumulating biomass, while the biomass at the old site reached a stable state. The model consistently underestimates the residence time of phosphorus $\mathrm{P}_{\mathrm{MRT}}$, which can be attributed to an underestimation of the phosphorus content of stems and coarse roots (not shown). 
Author contributions. DSG led the development of the representation of the phosphorus cycle and its implementation in ORCHIDEE, and performed all simulations and analysis. FM, AJ, and NV assisted with technical aspects of the model and its run environment. $\mathrm{NV}$ performed the re-implementation of the nitrogen cycle from a discontinued version of ORCHIDEE (now OCN) in a recent version of ORCHIDEE. SZ assisted in revising the nitrogen cycle to be consistent with OCN. AV provided estimates of soil phosphorus parameters from the P-WITCH mechanistic phosphorus weathering model. JS and JP provided stoichiometric data of Metrosideros from their field campaigns as well as additional plant traits complied from the literature. MK assisted with the implementation of root phosphorus uptake and soil phosphorus diffusion. IJ, JP, PC, and MO contributed to the theoretical concept of phosphorus cycling and its interactions with the biotic and abiotic environments. SP, YS, MG, and BG assisted in ensuring consistency between the nutrient cycles and various other processes in ORCHIDEE. All authors contributed with their comments to the writing of the manuscript.

Competing interests. The authors declare that they have no conflict of interest.

Acknowledgements. D. S. Goll is funded by the IMBALANCE-P project of the European Research Council (ERC-2013-SyG610028). S. Zaehle was supported by the QUINCY project of the European Research Council (ERC-2014-CoG-647204). We thank two anonymous referees and the editor H. Sato for their constructive comments. Further, we thank the TRY initiative and database, which is hosted, developed, and maintained by J. Kattge and G. Boenisch (Max Planck Institute for Biogeochemistry, Jena, DE), for additional leaf stoichiometric data on Metrosideros, YingPing Wang and Ben Houlton for sharing their data compilation on the Hawaiian sites, and Sebastiaan Luysseart for the discussions related to biomass allocation.

Edited by: Hisashi Sato

Reviewed by: Hisashi Sato and one anonymous referee

\section{References}

Amazon Fertilization Experiment (AFEX), available at: https:// amazonfertilisationexperiment.wordpress.com, last access: 9 October 2017

Ali, A. A., Xu, C., Rogers, A., Fisher, R. A., Wullschleger, S. D., Massoud, E. C., Vrugt, J. A., Muss, J. D., McDowell, N. G., Fisher, J. B., Reich, P. B., and Wilson, C. J.: A global scale mechanistic model of photosynthetic capacity (LUNA V1.0), Geosci. Model Dev., 9, 587-606, https://doi.org/10.5194/gmd-9587-2016, 2016.

AmazonFACE, available at: https://amazonface.org/, last access: 9 October 2017.

Bahar, N. H. A., Ishida, F. Y., Weerasinghe, L. K., Guerrieri, R., O’Sullivan, O. S., Bloomfield, K. J., Asner, G. P., Martin, R. E., Lloyd, J., Malhi, Y., Phillips, O. L., Meir, P., Salinas, N., Cosio, E. G., Domingues, T. F., Quesada, C. A., Sinca, F., Escudero Vega, A., Zuloaga Ccorimanya, P. P., del
Aguila-Pasquel, J., Quispe Huaypar, K., Cuba Torres, I., Butrón Loayza, R., Pelaez Tapia, Y., Huaman Ovalle, J., Long, B. M., Evans, J. R., and Atkin, O. K.: Leaf-level photosynthetic capacity in lowland Amazonian and high-elevation Andean tropical moist forests of Peru, New Phytol., 214, 1002-1018, https://doi.org/10.1111/nph.14079, 2016.

Barraclough, P. B. and Tinker, P. B.: The determination of ionic diffusion coefficients in field soils. I. Diffusion coefficients in sieved soils in relation to water content and bulk density, J. Soil Sci., 32, 225-236, https://doi.org/10.1111/j.13652389.1981.tb01702.x, 1981.

Barron, A. R., Wurzburger, N., Bellenger, J. P., Wright, S. J., Kraepiel, A. M. L., and Hedin, L. O.: Molybdenum limitation of asymbiotic nitrogen fixation in tropical forest soils, Nat. Geosci., 2, 42-45, https://doi.org/10.1038/ngeo366, 2009.

Bonan, G. B., Williams, M., Fisher, R. A., and Oleson, K. W. Modeling stomatal conductance in the earth system: linking leaf water-use efficiency and water transport along the soilplant-atmosphere continuum, Geosci. Model Dev., 7, 2193 2222, https://doi.org/10.5194/gmd-7-2193-2014, 2014.

Bouma, T. J., Yanai, R. D., Elkin, A. D., Hartmond, U., Flores-Alva, D. E., and Eissenstat, D. M.: Estimating agedependent costs and benefits of roots with contrasting life span: comparing apples and oranges, New Phytol., 150, 685-695, https://doi.org/10.1046/j.1469-8137.2001.00128.x, 2001.

Brovkin, V. and Goll, D.: Land unlikely to become large carbon source, Nat. Geosci., 8, 893, https://doi.org/10.1038/ngeo2598, 2015.

Campo, J. and Dirzo, R.: Leaf quality and herbivory responses to soil nutrient addition in secondary tropical dry forests of Yucatán, Mexico, J. Trop. Ecol., 19, 525-530, https://doi.org/10.1017/S0266467403003572, 2003.

Casotti, G. and Bradley, J. S.: Leaf nitrogen and its effects on the rate of herbivory on selected eucalypts in the jarrah forest, Forest Ecol. Manage., 41, 167-177, https://doi.org/10.1016/03781127(91)90101-Z, 1991.

Cernusak, L. A., Winter, K., Aranda, J., Turner, B. L., and Marshall, J. D.: Transpiration efficiency of a tropical pioneer tree (Ficus insipida) in relation to soil fertility, J. Exp. Bot., 58, 3549_ 3566, https://doi.org/10.1093/jxb/erm201, 2007.

Chadwick, O. A., Derry, L. A., Vitousek, P. M., Huebert, B. J., and Hedin, L. O.: Changing sources of nutrients during four million years of ecosystem development, Nature, 397, 491-497, 1999.

Chorover, J., Amistadi, M. K., and Chadwick, O. A.: Surface charge evolution of mineral-organic complexes during pedogenesis in Hawaiian basalt, Geochim. Cosmochim. Ac., 68, 4859-4876, https://doi.org/10.1016/j.gca.2004.06.005, 2004.

Cleveland, C. C., Townsend, A. R., Schimel, D. S., Fisher, H., Hedin, L. O., Perakis, S., Latty, E. F., Fischer, C. V., Elseroad, A., and Wasson, M. F.: Global patterns of terrestrial biological nitrogen $\left(\mathrm{N}_{2}\right)$ fixation in natural ecosystems, Global Biogeochem. Cy., 13, 623-645, https://doi.org/10.1029/1999GB900014, 1999.

Crews, T. E., Kitayama, K., Fownes, J. H., Riley, R. H., Darrell, A., Mueller-Dombois, D., and Vitousek, P. M.: Changes in soil phosphorus fractions and ecosystem dynamics across a long chronosequence in Hawaii, Ecology, 76, 1407-1424, 1995.

Crews, T. E., Kurina, L. M., and Vitousek, P. M.: Organic matter and nitrogen accumulation and nitrogen fixation during early 
ecosystem development in Hawaii, Biogeochemistry, 52, 259279, https://doi.org/10.1023/A:1006441726650, 2001.

De Kauwe, M. G., Medlyn, B. E., Zaehle, S., Walker, A. P., Dietze, M. C., Wang, Y.-P., Luo, Y., Jain, A. K., El-Masri, B., Hickler, T., Wårlind, D., Weng, E., Parton, W. J., Thornton, P. E., Wang, S., Prentice, I. C., Asao, S., Smith, B., McCarthy, H. R., Iversen, C. M., Hanson, P. J., Warren, J. M., Oren, R., and Norby, R. J.: Where does the carbon go? A model-data intercomparison of vegetation carbon allocation and turnover processes at two temperate forest free-air $\mathrm{CO}_{2}$ enrichment sites, New Phytol., 203, 883-899, https://doi.org/10.1111/nph.12847, 2014.

Doetterl, S., Stevens, A., Six, J., Merckx, R., Oost, K. V., Pinto, M. C., Casanova-Katny, A., Muñoz, C., Boudin, M., Venegas, E. Z., and Boeckx, P.: Soil carbon storage controlled by interactions between geochemistry and climate, Nat. Geosci., 8, 780-783, https://doi.org/10.1038/NGEO2516, 2015.

Domingues, T. F., Meir, P., Feldpausch, T. R., Saiz, G., Veenendaal, E. M., Schrodt, F., Bird, M., Djagbletey, G., Hien, F., Compaore, H., Diallo, A., Grace, J., and Lloyd, J.: Co-limitation of photosynthetic capacity by nitrogen and phosphorus in West Africa woodlands, Plant Cell Environ., 33, 959-980, https://doi.org/10.1111/j.1365-3040.2010.02119.x, 2010.

EucFACE, available at: https://www.westernsydney.edu.au/hie/ facilities/EucFACE, last access: 9 October 2017.

Finzi, A. C., Norby, R. J., Calfapietra, C., Gallet-Budynek, A., Gielen, B., Holmes, W. E., Hoosbeek, M. R., Iversen, C. M., Jackson, R. B., Kubiske, M. E., Ledford, J., Liberloo, M., Oren, R., Polle, A., Pritchard, S., Zak, D. R., Schlesinger, W. H., and Ceulemans, R.: Increases in nitrogen uptake rather than nitrogenuse efficiency support higher rates of temperate forest productivity under elevated $\mathrm{CO}_{2}$, P. Natl. Acad. Sci. USA, 104, 1401414019, https://doi.org/10.1073/pnas.0706518104, 2007.

Fox, T. R.: Rhizosphere activity and organic phosphorus in two forested, Soil Biol. Biochem., 24, 579-583, 1992.

Goddéris, Y., François, L. M., Probst, A., Schott, J., Moncoulon, D., Labat, D., and Viville, D.: Modelling weathering processes at the catchment scale: the WITCH numerical model, Geochim. Cosmochim. Ac., 70, 1128-1147, https://doi.org/10.1016/j.gca.2005.11.018, 2006.

Goll, D. S., Brovkin, V., Parida, B. R., Reick, C. H., Kattge, J., Reich, P. B., van Bodegom, P. M., and Niinemets, Ü.: Nutrient limitation reduces land carbon uptake in simulations with a model of combined carbon, nitrogen and phosphorus cycling, Biogeosciences, 9, 3547-3569, https://doi.org/10.5194/bg-9-35472012, 2012.

Goll, D. S., Moosdorf, N., Hartmann, J., and Brovkin, V.: Climate-driven changes in chemical weathering and associated phosphorus release since 1850: Implications for the land carbon balance, Geophys. Res. Lett., 41, 3553-3558, https://doi.org/10.1002/2014GL059471, 2014.

Harrington, R. A., Fownes, J. H., and Vitousek, P. M.: Production and resource use efficiencies in $\mathrm{N}$ - and P-limited tropical forests: a comparison of responses to long-term fertilization, Ecosystems, 4, 646-657, https://doi.org/10.1007/s10021001-0034-z, 2001.

Harris, I., Jones, P. D., Osborn, T. J., and Lister, D. H.: Updated high-resolution grids of monthly climatic observations - the CRU TS3.10, Int. J. Climatol., 34, 623-642, 2014.
Hartmann, H. and Trumbore, S.: Understanding the roles of nonstructural carbohydrates in forest trees - from what we can measure to what we want to know, New Phytol., 201, 386-403, https://doi.org/10.1111/nph.13955, 2016.

Hartmann, J. and Moosdorf, N.: The new global lithological map database GLiM: a representation of rock properties at the Earth surface, Geochem. Geophy. Geosy., 13, 1-37, https://doi.org/10.1029/2012GC004370, 2012.

Hartmann, J., Moosdorf, N., Lauerwald, R., Hinderer, M., and West, A. J.: Global chemical weathering and associated p-release - the role of lithology, temperature and soil properties, Chem. Geol., 363, 145-163, https://doi.org/10.1016/j.chemgeo.2013.10.025, 2014.

Heineman, K. D., Turner, B. L., and Dalling, J. W.: Variation in wood nutrients along a tropical soil fertility gradient, New Phytol., 211, 440-454, https://doi.org/10.1111/nph.13904, 2016.

Hofmann, K., Heuck, C., and Spohn, M.: Phosphorus resorption by young beech trees and soil phosphatase activity as dependent on phosphorus availability, Oecologia, 181, 369-379, https://doi.org/10.1007/s00442-016-3581-x, 2016.

Holloway, J. M.: Nitrogen in rock: occurrences and biogeochemical implications, Global Biogeochem. Cy., 16, 65-1-65-17, https://doi.org/10.1029/2002GB001862, 2002.

Ichie, T. and Nakagawa, M.: Dynamics of mineral nutrient storage for mast reproduction in the tropical emergent tree Dryobalanops aromatica, Ecol. Res., 28, 151-158, https://doi.org/10.1007/s11284-011-0836-1, 2013.

Effects of phosphorus limitations on Life, Earth system and Society (IMBALANCE-P), available at: http://imbalancep-erc.creaf.cat/, last access: 9 October 2017.

Johnson, A. H., Frizano, J., Vann, D. R., and Johnson, R. A. H.: Biogeochemical implications of labile phosphorus in forest soils determined by the Hedley fractionation procedure, Oecologia, 135, 487-499, https://doi.org/10.1007/s00442-002-1164-5, 2003.

Johnson, I. R. I. and Thornley, J.: A model of instantaneous and daily canopy photosynthesis, J. Theor. Biol., 107, 531-545, https://doi.org/10.1016/S0022-5193(84)80131-9, 1984.

Kattge, J. and Knorr, W.: Temperature acclimation in a biochemical model of photosynthesis: a reanalysis of data from 36 species, Plant Cell Environ., 30, 1176-1190, https://doi.org/10.1111/j.1365-3040.2007.01690.x, 2007.

Kattge, J., Knorr, W., Raddatz, T., and Wirth, C.: Quantifying photosynthetic capacity and its relationship to leaf nitrogen content for global-scale terrestrial biosphere models, Global Change Biol., 15, 976-991, https://doi.org/10.1111/j.1365-2486.2008.01744.x, 2009.

Kattge, J., Díaz, S., Lavorel, S., Prentice, I. C., Leadley, P., Bönisch, G., Garnier, E., Westoby, M., Reich, P. B., Wright, I. A. N. J., Cornelissen, J. H. C., Violle, C., Harrison, S. P., van Bodegom, P. M., Reichstein, M., Enquist, B. J., Soudzilovskaia, N. A., Ackerly, D. D., Anand, M., Atkin, O., Bahn, M., Baker, T. R., Baldocchi, D., Bekker, R., Blanco, C. C., Blonder, B., Bond, W. J., Bradstock, R., Bunker, D. E., Casanoves, F., Cavender-Bares, J., Chambers, J. Q., Chapin, F. S., Chave, J., Coomes, D., Cornwell, W. K., Craine, J. M., Dobrin, B. H., Duarte, L., Durka, W., Elser, J., Esser, G., Estiarte, M., Fagan, W. F., Fang, J., Fernández-Méndez, F., Fidelis, A., Finegan, B., Flores, O., Ford, H., Frank, D., Freschet, G. T., Fyllas, N. M., Gal- 
lagher, R. V., Green, W. A., Gutierrez, A. G., Hickler, T., Higgins, S., Hodgson, J. G., Jalili, A., Jansen, S., Joly, C., Kerkhoff, A. J., Kirkup, D. O. N., Kitajima, K., Kleyer, M., Klotz, S., Knops, J. M. H., Kramer, K., Kühn, I., Kurokawa, H., Laughlin, D., Lee, T. D., Leishman, M., Lens, F., Lenz, T., Lewis, S. L., Lloyd, J. O. N., Llusià, J., Louault, F., Ma, S., Mahecha, M. D., Manning, P., Massad, T., Medlyn, B., Messier, J., Moles, A. T., Müller, S. C., Nadrowski, K., Naeem, S., Niinemets, Ü. L. O., Nöllert, S., Nüske, A., Ogaya, R., Oleksyn, J., Onipchenko, V. G., Onoda, Y., Ordoñez, J., Overbeck, G., Ozinga, W. I. M. A., Patiño, S., Paula, S., Pausas, J. G., Peñuelas, J., Phillips, O. L., Pillar, V., Poorter, H., Poorter, L., Poschlod, P., Prinzing, A., Proulx, R., Rammig, A., Reinsch, S., Reu, B., Sack, L., Salgado-Negret, B., Sardans, J., Shiodera, S., Shipley, B., Siefert, A., Sosinski, E., Soussana, J.-F., Swaine, E., Swenson, N., Thompson, K. E. N., Thornton, P., Waldram, M., Weiher, E., White, M., White, S., Wright, S. J., Yguel, B., Zaehle, S., Zanne, A. M. Y. E., and Wirth, C.: TRY - a global database of plant traits, Global Change Biol., 17, 2905-2935, https://doi.org/10.1111/j.1365-2486.2011.02451.x, 2011.

Kirschbaum, M. U. F., Simioni, G., Medlyn, B. E., and McMurtrie, R. E.: On the importance of including soil nutrient feedback effects for predicting ecosystem carbon exchange, Funct. Plant Biol., 30, 223-237, https://doi.org/10.1071/FP02152, 2003.

Koerselman, W. and Meuleman, A. F. M. A.: The vegetation N : P ratio: a new tool to detect the nature of nutrient limitation, J. Appl. Ecol., 33, 1441-1450, https://doi.org/10.2307/2404783, 1996.

Krinner, G., Viovy, N., de Noblet-Ducoudré, N., Ogée, J., Polcher, J., Friedlingstein, P., Ciais, P., Sitch, S., and Prentice, I. C.: A dynamic global vegetation model for studies of the coupled atmosphere-biosphere system, Global Biogeochem. Cy., 19, 1-33, https://doi.org/10.1029/2003GB002199, 2005.

Kronzucker, H. J., Siddiqi, M. Y., and Glass, A. D. M.: Kinetics of $\mathrm{NO}_{3}^{-}$influx in spruce, Plant Physiol., 109, 319-326, 1995.

Lawrence, D.: Nitrogen and Phosphorus Enhance Growth and Luxury Consumption of Four Secondary Forest Tree Species in Borneo, Cambridge University Press, available at: http://www.jstor. org/stable/3068619, also at: J. Trop. Ecol., 17, 859-869, 2001.

Li, X. L., George, E., and Marschner, H.: Extension of the phosphorus depletion zone in VA-mycorrhizal white clover in a calcareous soil, Plant Soil, 136, 41-48, https://doi.org/10.1007/BF02465219, 1991.

Lovelock, C. E., Ball, M. C., Choat, B., Engelbrecht, B. M. J., Holbrook, N. M., and Feller, I. C.: Linking physiological processes with mangrove forest structure: phosphorus deficiency limits canopy development, hydraulic conductivity and photosynthetic carbon gain in dwarf Rhizophora mangle, Plant, Cell Environ., 29, 793-802, https://doi.org/10.1111/j.1365-3040.2005.01446.x, 2006.

Margalef, O., Sardans, J., Fernández-Martínez, M., MolownyHoras, R., Janssens, I. A., Ciais, P., Goll, D., Richter, A., Obersteiner, M., Asensio, D., and Peñuelas, J.: Global patterns of phosphatase activity in natural soils, Sci. Rep., 7, 1337, https://doi.org/10.1038/s41598-017-01418-8, 2017.

Marotzke, J., Jakob, C., Bony, S., Dirmeyer, P. A., O'Gorman, P. A., Hawkins, E., Perkins-Kirkpatrick, S., Quéré, C. L., Nowicki, S., Paulavets, K., Seneviratne, S. I., Stevens, B., and Tuma, M.: Cli- mate research must sharpen its view, Nat. Clim. Change, 7, 8991, https://doi.org/10.1038/nclimate3206, 2017.

McGechan, M. and Lewis, D.: Sorption of phorphorus by soil, Part 1: Principles, equations and models, Biosyst. Eng., 82, 124, https://doi.org/10.1006/bioe.2002.0054, 2002.

McGill, W. B. and Cole, C. V.: Comparative aspects of cycling of organic $\mathrm{C}, \mathrm{N}, \mathrm{S}$, and $\mathrm{P}$ through soil organic matter, Geoderma, 26, 267-268, 1981.

McGroddy, M. E., Daufresne, T., and Hedin, L. O.: Scaling of $\mathrm{C}: \mathrm{N}: \mathrm{P}$ stoichiometry in forest worldwide: implications of terrestrial redfield-like ratios, Ecology, 85, 2390-2401, 2004.

Medlyn, B. E., Kauwe, M. G. D., Walker, A. P., Dietze, C., Hanson, P., Hickler, T., Jain, A., Luo, Y., Parton, W., Colin, I., Wang, S., Wang, Y.-P., Weng, E., Iversen, C. M., Mccarthy, H., Warren, J., Oren, R., Norby, R., Division, E. S., Ridge, O., Goethe, G., and Collins, F.: Using ecosystem experiments to improve vegetation models: lessons learnt from the free-air $\mathrm{CO}_{2}$ enrichment model-data synthesis, Nat. Clim. Change, 5, 528-534, https://doi.org/10.1038/nclimate2621, 2015.

Meyerholt, J. and Zaehle, S.: The role of stoichiometric flexibility in modelling forest ecosystem responses to nitrogen fertilization, New Phytol., 208, 1042-1055, https://doi.org/10.1111/nph.13547, 2015.

Mollier, A., De Willigen, P., Heinen, M., Morel, C. Schneider, A., and Pellerin, S.: A two-dimensional simulation model of phosphorus uptake including crop growth and P-response, Ecol. Model., 210, 453-464, https://doi.org/10.1016/j.ecolmodel.2007.08.008, 2008.

Mooshammer, M., Wanek, W., Hämmerle, I., Fuchslueger, L., Hofhansl, F., Knoltsch, A., Schnecker, J., Takriti, M., Watzka, M., Wild, B., Keiblinger, K. M., ZechmeisterBoltenstern, S., and Richter, A.: Adjustment of microbial nitrogen use efficiency to carbon: nitrogen imbalances regulates soil nitrogen cycling, Nat. Commun., 5, 3694, https://doi.org/10.1038/ncomms4694, 2014.

Morford, S. L., Houlton, B. Z., and Dahlgren, R. A.: Increased forest ecosystem carbon and nitrogen storage from nitrogen rich bedrock, Nature, 477, 78-81, https://doi.org/10.1038/nature10415, 2011.

Naudts, K., Ryder, J., McGrath, M. J., Otto, J., Chen, Y., Valade, A., Bellasen, V., Berhongaray, G., Bönisch, G., Campioli, M., Ghattas, J., De Groote, T., Haverd, V., Kattge, J., MacBean, N., Maignan, F., Merilä, P., Penuelas, J., Peylin, P., Pinty, B., Pretzsch, H., Schulze, E. D., Solyga, D., Vuichard, N., Yan, Y., and Luyssaert, S.: A vertically discretised canopy description for ORCHIDEE (SVN r2290) and the modifications to the energy, water and carbon fluxes, Geosci. Model Dev., 8, 2035-2065, https://doi.org/10.5194/gmd-8-2035-2015, 2015.

Niu, Y. F., Chai, R. S., Jin, G. L., Wang, H., Tang, C. X., and Zhang, Y. S.: Responses of root architecture development to low phosphorus availability: a review, Ann. Bot.-Lond., 112, 391408, https://doi.org/10.1093/aob/mcs285, 2013.

Norby, R. J., Gu, L., Haworth, I. C., Jensen, A. M., Turner, B. L., Walker, A. P., Warren, J. M., Weston, D. J., Xu, C., and Winter, K.: Informing models through empirical relationships between foliar phosphorus, nitrogen and photosynthesis across diverse woody species in tropical forests of Panama, New Phytol., 215, 1425-1437, https://doi.org/10.1111/nph.14319, 2016. 
Olander, L. P. and Vitousek, P. M.: Regulation of soil phosphatase and chitinase activity by $\mathrm{N}$ and $\mathrm{P}$ availability, Biogeochemistry, 49, 175-190, https://doi.org/10.1023/A:1006316117817, 2000.

Olander, L. P. and Vitousek, P. M.: Biological and geochemical sinks for phosphorus in soil from a wet tropical forest, Ecosystems, 7, 404-419, https://doi.org/10.1007/s10021-004-0264-y, 2004.

Olesen, T., Moldrup, P., Yamaguchi, T., and Rolston, D. E.: Constant slope impedance factor model for predicting the solute diffusion coefficient in unsaturated soil, Soil Sci., 166, 89-96, https://doi.org/10.1097/00010694-200102000-00002, 2001.

Ostertag, R. E. O.: Fine-root dynamics in Hawaiian Montane forests, Ecology, 82, 485-499, 2001.

Parton, W. J., Scurlock, J. M. O., Ojima, D. S., Gilmanov, T. G., Scholes, R. J., Schimel, D. S., Kirchner, T., Menaut, J.-C., Seastedt, T. R., Garcia Moya, E., Kamnalrut, A., and Kinyamario, J. I.: Observations and modeling of biomass and soil organic matter dynamics for the grassland biome worldwide, Global Biogeochem. Cy., 7, 785-809, https://doi.org/10.1029/93GB02042, 1993.

Peñuelas, J., Poulter, B., Sardans, J., Ciais, P., van der Velde, M., Bopp, L., Boucher, O., Godderis, Y., Hinsinger, P., Llusia, J., Nardin, E., Vicca, S., Obersteiner, M., and Janssens, I. A.: Human-induced nitrogen-phosphorus imbalances alter natural and managed ecosystems across the globe, Nat. Commun., 4, 2934, https://doi.org/10.1038/ncomms3934, 2013.

Piper, F. I. and Fajardo, A.: Foliar habit, tolerance to defoliation and their link to carbon and nitrogen storage, J. Ecol., 102, 11011111, https://doi.org/10.1111/1365-2745.12284, 2014.

Quantifying the effects of interacting nutrient cycles on terrestrial biosphere dynamics and their climate feedbacks (QUINCY), available at: https://www.bgc-jena.mpg.de/bgi/index.php/ Projects/QUINCY, last access: 9 October 2017.

Reed, S. C., Yang, X., and Thornton, P. E.: Incorporating phosphorus cycling into global modeling efforts: a worthwhile, tractable endeavor, New Phytol., 208, 324-329, https://doi.org/10.1111/nph.13521, 2015.

Reich, P. B., Oleksyn, J., and Wright, I. J.: Leaf phosphorus influences the photosynthesis-nitrogen relation: a crossbiome analysis of 314 species, Oecologia, 160, 207-212, https://doi.org/10.1007/s00442-009-1291-3, 2009.

Santiago, L. S.: Nutrient limitation of eco-physiological processes in tropical trees, Trees, 29, 1291-1300, https://doi.org/10.1007/s00468-015-1260-x, 2015.

Sardans, J., Janssens, I. A., Alonso, R., Veresoglou, S. D., Rillig, M. C., Sanders, T. G., Carnicer, J., Filella, I., FarréArmengol, G., and Peñuelas, J.: Foliar elemental composition of European forest tree species associated with evolutionary traits and present environmental and competitive conditions, Global Ecol. Biogeogr., 24, 240-255, https://doi.org/10.1111/geb.12253, 2015.

Schachtman, D. P., Reid, R. J., and Ayling, S. M.: Phosphorus uptake by plants: from soil to cell, Plant Physiol., 116, 447-453, 1998.

Shcherbak, I., Millar, N., and Robertson, G. P.: Global metaanalysis of the nonlinear response of soil nitrous oxide $\left(\mathrm{N}_{2} \mathrm{O}\right)$ emissions to fertilizer nitrogen, P. Natl. Acad. Sci. USA, 111, 9199-9204, https://doi.org/10.1073/pnas.1322434111, 2014.
Shinozaki, K., Yoda, K., Hozumi, K., and Kira, T.: A quantitative analysis of plant form - the pipe model theory: I Basix analysis, Jpn. J. Ecol., 14, 97-105, 1964.

Smith, B., Wårlind, D., Arneth, A., Hickler, T., Leadley, P., Siltberg, J., and Zaehle, S.: Implications of incorporating $\mathrm{N}$ cycling and $\mathrm{N}$ limitations on primary production in an individualbased dynamic vegetation model, Biogeosciences, 11, 20272054, https://doi.org/10.5194/bg-11-2027-2014, 2014.

Spohn, M. and Kuzyakov, Y.: Phosphorus mineralization can be driven by microbial need for carbon, Soil Biol. Biochem., 61, 69-75, https://doi.org/10.1016/j.soilbio.2013.02.013, 2013.

SPP: Forest Strategies for limited Phosphorus Resources (SPP1685), available at: www.ecosystem-nutrition.uni-freiburg. de, last access: 9 October 2017.

Stewart, J. W. B. and Tiessen, H.: Dynamics of soil organic phosphorus, Biogeochemistry, 4, 41-60, https://doi.org/10.1007/BF02187361, 1987.

Thomas, R. Q., Zaehle, S., Templer, P. H., and Goodale, C. L.: Global patterns of nitrogen limitation: confronting two global biogeochemical models with observations, Global Change Biol., 19, 2986-2998, https://doi.org/10.1111/gcb.12281, 2013.

Thornton, P. E., Lamarque, J.-F., Rosenbloom, N. A., and Mahowald, N. M.: Influence of carbon-nitrogen cycle coupling on land model response to $\mathrm{CO}_{2}$ fertilization and climate variability, Global Biogeochem. Cy., 21, 1-15, https://doi.org/10.1029/2006GB002868, 2007.

Thornton, P. E., Thornton, M., and Vose, R.: Daymet V3: Annual Tile Summary Cross-Validation Statistics for North America, Hawaii, Tech. rep., ORNL DAAC, Oak Ridge, Tennessee, USA, https://doi.org/10.3334/ORNLDAAC/1348, 2016.

Tipping, E., Somerville, C. J., and Luster, J.: The C:N : P:S stoichiometry of soil organic matter, Biogeochemistry, 130, 117131, https://doi.org/10.1007/s10533-016-0247-z, 2016.

Van Wijk, M. T., Williams, M., Cough, L., Hobbie, S. E., and Shaver, G. R.: Luxury consumption of soil nutrients: a possible competitive strategy in above-ground and below-ground biomass allocation and root morphology for slow-growing arctic vegetation?, J. Ecol., 91, 664-676, https://doi.org/10.1046/j.13652745.2003.00788.x, 2003.

Verheijen, L. M., Aerts, R., Bönisch, G., Kattge, J., and Van Bodegom, P. M.: Variation in trait trade-offs allows differentiation among predefined plant functional types: implications for predictive ecology, New Phytol., 209, 563-575, https://doi.org/10.1111/nph.13623, 2016.

Vitousek, P. M.: Nutrient Cycling and Limitation: Hawaii as a Model System, Princeton University Press, Princeton, NJ, USA, 2004.

Vitousek, P. M., Menge, D. N. L., Reed, S. C., and Cleveland, C. C.: Biological nitrogen fixation: rates, patterns and ecological controls in terrestrial ecosystems, Philos. T. Roy. Soc. B, 368, 20130119, https://doi.org/10.1098/rstb.2013.0119, 2013.

Walker, A. P., Beckerman, A. P., Gu, L., Kattge, J., Cernusak, L. A., Domingues, T. F., Scales, J. C., Wohlfahrt, G., Wullschleger, S. D., and Woodward, F. I.: The relationship of leaf photosynthetic traits $-\mathrm{V}$ cmax and $\mathrm{J} \max$ - to leaf nitrogen, leaf phosphorus, and specific leaf area: a metaanalysis and modeling study, Ecol. Evol., 16, 3218-3235, https://doi.org/10.1002/ece3.1173, 2014. 
Walker, A. P., Zaehle, S., Medlyn, B. E., De Kauwe, M. G., Asao, S., Hickler, T., and Norby, R. J.: Predicting long-term carbon sequestration in response to $\mathrm{CO}_{2}$ enrichment: how and why do current ecosystem models differ?, Global Biogeochem. Cy., 5, 1-20, https://doi.org/10.1002/2014GB004995, 2015.

Walker, T. W. and Syers, J. K.: The fate of phosphorus during pedogenesis, Geoderma, 15, 1-19, https://doi.org/10.1016/00167061(76)90066-5, 1976.

Wang, F., Cheruy, F., and Dufresne, J.-L.: The improvement of soil thermodynamics and its effects on land surface meteorology in the IPSL climate model, Geosci. Model Dev., 9, 363-381, https://doi.org/10.5194/gmd-9-363-2016, 2016.

Wang, Y.-P., Houlton, B. Z., and Field, C. B.: A model of biogeochemical cycles of carbon, nitrogen, and phosphorus including symbiotic nitrogen fixation and phosphatase production, Global Biogeochem. Cy., 21, 1-15, https://doi.org/10.1029/2006GB002797, 2007.

Wang, Y. P., Law, R. M., and Pak, B.: A global model of carbon, nitrogen and phosphorus cycles for the terrestrial biosphere, Biogeosciences, 7, 2261-2282, https://doi.org/10.5194/bg-7-22612010, 2010.

Wieder, W. R., Cleveland, C. C., Lawrence, D. M., and Bonan, G. B.: Effects of model structural uncertainty on carbon cycle projections: biological nitrogen fixation as a case study, Environ. Res. Lett., 10, 044016, https://doi.org/10.1088/17489326/10/4/044016, 2015.

Yang, X. and Post, W. M.: Phosphorus transformations as a function of pedogenesis: A synthesis of soil phosphorus data using Hedley fractionation method, Biogeosciences, 8, 2907-2916, https://doi.org/10.5194/bg-8-2907-2011, 2011.
Yang, X., Post, W. M., Thornton, P. E., and Jain, A.: The distribution of soil phosphorus for global biogeochemical modeling, Biogeosciences, 10, 2525-2537, https://doi.org/10.5194/bg-102525-2013, 2013.

Yang, X., Thornton, P. E., Ricciuto, D. M., and Post, W. M.: The role of phosphorus dynamics in tropical forests - a modeling study using CLM-CNP, Biogeosciences, 11, 1667-1681, https://doi.org/10.5194/bg-11-1667-2014, 2014.

Zaehle, S. and Friend, A. D.: Carbon and nitrogen cycle dynamics in the O-CN land surface model: 1. Model description, site-scale evaluation, and sensitivity to parameter estimates, Global Biogeochem. Cy., 24, 1-13, https://doi.org/10.1029/2009GB003521, 2010.

Zaehle, S., Ciais, P., Friend, A. D., and Prieur, V.: Carbon benefits of anthropogenic reactive nitrogen offset by nitrous oxide emissions, Nat. Geosci., 4, 601-605, https://doi.org/10.1038/ngeo1207, 2011.

Zaehle, S., Medlyn, B. E., Kauwe, M. G. D., Walker, A. P., Dietze, M. C., Hickler, T., Luo, Y., Wang, Y.-P., El-Masri, B., Thornton, P., Jain, A., Wang, S., Warlind, D., Weng, E., Parton, W., Iversen, C. M., Gallet-Budynek, A., Mccarthy, H., Finzi, A. C., Hanson, P. J., Prentice, I. C., Oren, R., and Norby, R. J.: Evaluation of 11 terrestrial carbon - nitrogen cycle models against observations from two temperate FreeAir $\mathrm{CO}_{2}$ Enrichment studies, New Phytol., 202, 803-822, https://doi.org/10.1111/nph.12697, 2014.

Zhang, Z., Rengel, Z., and Meney, K.: Kinetics of ammonium, nitrate and phosphorus uptake by Canna indica and Schoenoplectus validus, Aquat. Bot., 91, 71-74, https://doi.org/10.1016/j.aquabot.2009.02.002, 2009. 